Article

\title{
Can Organic Farming Reduce Vulnerabilities and Enhance the Resilience of the European Food System? A Critical Assessment Using System Dynamics Structural Thinking Tools
}

\author{
Natalia Brzezina ${ }^{1, *}$, Birgit Kopainsky ${ }^{2}$ and Erik Mathijs ${ }^{1}$ \\ 1 Sustainable Food Economies Research Group, KU Leuven, Leuven 3001, Belgium; erik.mathij@@kuleuven.be \\ 2 System Dynamics Group, University of Bergen, Bergen 5020, Norway; birgit.kopainsky@uib.no \\ * Correspondence: natalia.brzezina@kuleuven.be; Tel.: +32-466-141-702 \\ Academic Editor: Sean Clark \\ Received: 30 June 2016; Accepted: 14 September 2016; Published: 24 September 2016
}

\begin{abstract}
In a world of growing complexity and uncertainty, food systems must be resilient, i.e., able to deliver sustainable and equitable food and nutrition security in the face of multiple shocks and stresses. The resilience of the European food system that relies mostly on conventional agriculture is a matter of genuine concern and a new approach is called for. Does then organic farming have the potential to reduce vulnerabilities and improve the resilience of the European food system to shocks and stresses? In this paper, we use system dynamics structural thinking tools to identify the vulnerabilities of the conventional food system that result from both its internal structure as well as its exposure to external disturbances. Further, we evaluate whether organic farming can reduce the vulnerabilities. We argue here that organic farming has some potential to bring resilience to the European food system, but it has to be carefully designed and implemented to overcome the contradictions between the dominant socio-economic organization of food production and the ability to enact all organic farming's principles—-health, ecology, fairness and care—on a broader scale.
\end{abstract}

Keywords: conventional agriculture; organic farming; system dynamics; food system; food and nutrition security; vulnerability; resilience; feedback loops; causal loop diagram

\section{Introduction}

Food is of key relevance to human health and survival. Europeans take their food and nutrition security (FNS) for granted and rely on a food system in which most of the food is produced by conventional farmers subsidized from the Common Agriculture Policy (CAP) [1]. Over the last decades this system, hugely depending on public support, has achieved tremendous improvements in productivity [2]. As a result, nowadays more food is supplied than demanded at historically low prices. This allows European consumers to spend only a small percentage of their household disposable income on food [1,3].

These FNS achievements in Europe are, however, far from ideal and looking ahead Europeans may not be as food secure as they perceive themselves to be. Most of the European consumers rely on a complex system, in which conventional farmers, driven by profit maximization, are continuously intensifying, specializing, standardizing, expanding their operations and becoming even more dependent on the application of off-farm sourced modern tools such as chemicals to manage fertility and pests, diesel-powered machines, biotechnology and proprietary seeds [2]. These processes and practices, in turn, feed back to the environment and to society with numerous unintended consequences, inter alia, soil degradation, nutrient runoff, greenhouse gas (GHG) emissions, biodiversity loss, pesticide-born health damage and socio-economic decline in rural communities. 
These consequences pose risks to FNS and well-being of future generations [4]. Moreover, much of the productivity advances and associated trends in the European food system were realized in times of relatively stable climate, when natural resources seemed to be infinite, and the human population was considerably smaller $[5,6]$. In the face of already observed changing climate, deteriorating natural resources, growing population largely driven by migration as well as many other emerging challenges and uncertainties, there are growing concerns that the European food system is vulnerable and thus unable to withstand disturbances without undesirable outcomes [1,5,7-14].

In order to cope with the challenges and uncertainties, we need a new approach to agriculture in the food system $[7,8,15]$. Such an approach must change both the farming practices as well as the socio-economic organization of food production to increase the food system's resilience and its ability to deliver sustainable and equitable FNS today and in the future [1,5,7-9]. One of the potential candidates is organic farming $[5,7,9,16]$, which from all the alternate approaches is the only one that has been regulated and supported at EU level by a vast array of legal, financial and knowledge-based policy instruments for several decades [17,18]. Accordingly, the number of organic farms, the extent of organically farmed land, funding devoted to organic farming and the market size for organic foods have steadily increased across Europe [18].

Given this development, an important question that arises is whether organic farming can reduce the vulnerabilities and enhance the resilience of the European food system and hence deliver sustainable and equitable FNS? Organic farming seems to be a promising approach as it is built on four systemic principles formulated by the International Federation of Organic Agriculture Movements (IFOAM): "health", "ecology", "fairness" and "care". Organic farming thus aims to produce wholesome food in an environmentally-friendly way, as well as to contribute to economic sustainability and social justice [19-21]. In research and public debate, however, organic farming has a history of being contentious [21]. At the same time, understanding and operationalization of the concepts of the food system's vulnerability and resilience themselves is limited [22]. On the one hand, many studies provide evidence for organic farming's ability to balance the multiple sustainability goals $[19,21]$ and build resilience to disturbances, especially at farm level [23-27]. On the other hand, critics consider organic farming as an inefficient approach to FNS, one that will become irrelevant in the future, because of too many shortcomings and poor solutions to agriculture problems [4,19-21]. Furthermore, some argue that organic farming undergoes 'conventionalization' and is a mere substitution of inputs rather than a redesign of farming operations [28]. Consequently, organic farming may violate many of the ecologically, socially and economically progressive principles originally valued $[20,21,28]$, further exacerbating vulnerabilities and undermining resilience of the European food system [5].

With regard to the nature of the assessments on which the debate draws, the majority is based on comparisons of outcomes delivered by organic versus conventional farming system (e.g., crop yields, profitability, environmental impacts, etc.) (e.g., [21,29-33]) as well as individual causal connections (e.g., the effect of organic farming practices on biodiversity, food quality or crop yield, etc.) ([34-36]), at a given point in time. A system's perspective over time is, however, missing. Food systems, no matter whether they are based on conventional, organic or any other food production approach, are dynamic and complex social-ecological systems (SES) [37]. Their structures are formed by many internal and external variables which interact with each other often across multiple, hierarchically linked subsystems [38] and through feedback mechanisms to generate outcomes [39,40]. These feedback mechanisms are largely masked to farmers, consumers and policymakers [11]. They also involve nonlinearities, time delays and accumulations, which complicate information and material flows in the food system and hence lead to counterintuitive system behavior [15,41]. Inherent to these features of food systems such as SES are the synergies and trade-offs between outcomes that they produce [37,40,41]. Given the dynamic complexity inherent in food systems, it is not immediately apparent where and how the vulnerabilities to disturbances occur in the system and how resilience is generated. Therefore, it is challenging for decision makers to design and implement effective strategies 
to farming and other aspects related to food systems that would reduce its vulnerabilities and enhance its resilience [15].

Conceptualizing and modelling of SES has the potential to assist decision makers in managing complex human-environment relationships that form the basis of food systems [42,43]. The development of SES models is, however, challenging as it requires inter alia integration of knowledge scattered across many disciplines on variables and their relationships from both the social and the ecological domains as well as explicit modelling of feedbacks between the social and ecological systems along with their cross-scale and cross-level interactions [38,42-44]. There are various approaches to the interdisciplinary modelling of SES with differing underlying assumptions and anchored in different scientific perspectives, so there is always the likelihood that another model of a particular food system might give diverse outcomes [43,44].

In this paper, we adopt a system dynamics approach [45] to understand the European food system's vulnerabilities and to assess the potential of organic farming to reduce them and enhance its resilience [15] through sustainability lenses. System dynamics is a computer-aided modelling approach to policy analysis and design that takes an explicit feedback perspective and enables capturing the dynamic complexity of SES, such as the food systems [40-42]. This approach is based on the underlying assumption that the internal structure and the feedback processes in a system determine its dynamic behavior over time and how it responds to disturbances $[15,45]$. By adopting this approach we do not provide new data, introduce new variables or measure the strengths of a particular causal-effect link. Rather, our main contribution is the reorganization of existing knowledge and the promotion of structural insights from variables already established in the literature. More specifically, we combine an in-depth literature review and secondary data analysis with system dynamics diagramming tools to fulfill three objectives. The first objective is to understand the different sources of vulnerabilities in the European food system based on conventional agriculture by analyzing its internal structure and feedback processes, where the entry points for disturbances are, and the mechanisms by which the disturbances are transmitted throughout the system. The second objective is to assess whether organic farming is a viable strategy to reduce the vulnerabilities and enhance the resilience of the European food system. The third objective is to illustrate throughout the analyses how the system dynamics approach can address some of the current challenges posed by SES modelling. Ultimately, we provide decision makers-e.g., policymakers, NGOs, farm associations, etc.-at EU level with a framework that could support them in developing more effective strategies for the European food system.

The remainder of the paper is organized as follows: after a brief overview of the conceptual background and methodology, we articulate the dynamic problem (i.e., select the system's boundary) and conceptualize the European food system from a feedback perspective. Next, we qualitatively analyze the food system's vulnerabilities by focusing on the interplay between internal structure and feedback processes of the system and external disturbances. Finally, we discuss organic farming as an alternative approach and close the paper with conclusions.

\section{Methodology: System Dynamics Structural Thinking Tools for Food System and Vulnerability Analysis}

Food systems are coupled SES formed by many internal and external variables that are interconnected through feedback processes at various scales and levels and that determine FNS along with other environmental and socio-economic outcomes [38-40,46,47]. When exposed to various and unforeseen disturbances, the emergence of undesirable outcomes indicates that somewhere in the food system a critical capacity is failing and that the structure and processes driving the functioning of the system make it vulnerable [47]. We thus define vulnerability as a system's inability to respond to disturbances without generating undesirable outcomes. In vulnerable food systems, even small disturbances may cause detrimental changes from which it is difficult to recover $[15,39,47]$. Resilience, on the other hand, is the capacity of a food system to withstand disturbances and continue providing the same or possibly even improved desirable outcomes [47]. Vulnerability and resilience are dynamic 
and normative concepts in the sense that the value judgement of what is desirable and what constitutes improvement or damage over what period of time depends on the observer [47,48]. Hence, to assess whether a food system is resilient or vulnerable we have to define: (1) the boundaries of the system (vulnerability/resilience of what); (2) relevant disturbances (vulnerability/resilience to what) and (3) what constitutes desirable change over what time frame and to whom $[47,48]$. We address these questions by adopting a system dynamics approach.

System dynamics is an approach designed to examine and manage complex systems that change over time. It is applicable to any dynamic systems of which integral features are interdependence, mutual interaction and feedback loops $[45,49,50]$. System dynamics modelling is an iterative process that begins with defining dynamic problem, proceeds through developing dynamic hypothesis and modeling stages, to building confidence in the model and analyzing policy implications $[45,49,50]$.

Conceptually, the central principle of this modelling approach is that the endogenous structure of a system determines its dynamic behavior over time and how it responds to disturbances and policy changes $[16,46]$. Thus, in system dynamics the emphasis is given to a continuous view (i.e., 'the large picture'), shifting the attention from events to behavior to structure. The endogenous point of view implies that the causes are contained within the internal structure of the system itself, while exogenous disturbances are seen at most as triggers of system behavior. Feedback loops are central for conceptualizing the internal structure of complex systems. These closed loops of causal links involve delays and nonlinearities as well as processes of accumulation and draining. The internal structure of a system is a combination of such feedback loops, which by interacting with each other can generate all kinds of dynamic patterns of behavior. However, the concept of underlying feedback loops is not exhaustive for explaining the dynamic behavior of a system. The explanatory power of feedback understanding lies in the shifting interplay between loops, implying that different parts of a system become dominant over the others at different times [50-52].

The system dynamics methodology provides structural thinking tools—closed boundary, feedback loops, stocks, flows, etc.- - used to communicate the boundary of the system and to represent its causal structure in a structural diagram. The goal of a system dynamics modeler is to assemble such a structural diagram that can endogenously, by itself, explain the dynamic problem. The closed boundary refers to the effort to view a system as causally closed as opposed to the open and closed systems in the general system sense. In turn, causality refers to causes as pressures which produce aggregated patterns of behavior rather than events, actions, individual stimuli and decisions [52]. This implies that feedback processes between levels (such as agriculture production and consumption) can be captured providing that the individual levels are modelled in an aggregated way [41]. The causally closed system boundary identifies the endogenous perspective as the feedback view pressed to an extreme. A causally closed structural diagram provides important qualitative insights into the system's behavior [15,53-55] and can facilitate the identification of leverage points for intervention in the system [15]. Based on structural diagrams computer simulation models can be created to experiment on how the system behaves under unanticipated disturbances or policy interventions $[15,55,56]$.

The theoretical assumptions of system dynamics have been addressed in several studies (e.g., [51,52,54-63]), but usually system dynamists take them for granted. System dynamics appears to be ontologically a realist approach, as models are presented as abstract representations of the real physical and information flows in a system, with feedbacks implying that, "decisions are not entirely 'free will' but are strongly conditioned by the environment" [51]. However, this objective stance of system dynamics models mixes with subjectivity, as the purpose of system dynamics is also to engage with 'mental models'. These mental models range from hard, quantitative information to more subjective, or even judgmental aspects of a given situation [57-59]. In consequence, a model should be focused around a particular issue (dynamic problem). The focus on trying to understand the real-world phenomena reflects the practical engineering origin of system dynamics [58]. From social theoretic perspective, however, divergent practice within this field makes it difficult to place it in one paradigm. Superficially, system dynamics can be positioned within the functionalist sociology paradigm, its ideas 
seeming to be a version of social systems theory $[58,62,63]$. However, the practice of system dynamics, and hence its theory in use, has many features of more interactionist paradigm and also some links to interpretativism $[58,62,63]$. The uncertainty related to positioning system dynamics within a social theoretic perspective leads to the conclusion that this approach appears to be best locatable within those theories that try to integrate the agency and structure views of the social realm (for detailed analysis see $[52,58,62,63])$.

In this paper, we adapt the approach taken by Stave and Kopainsky [15]. They used system dynamics to promote qualitative structural insights on mechanisms and pathways of food supply vulnerability, arguing that "any examination of food supply vulnerability to disturbances, or ability to withstand disturbances that could lead to food supply disruption, should start by examining the food system's components, causal connections, and feedback mechanisms and describing system interactions in terms of material and information flows that pass changes in one component on to other components" [15]. The approach taken in this study consists of three iterative steps inspired by the system dynamics modelling process: 1 . problem articulation; 2 . system conceptualization as well as 3 . vulnerability and policy analysis $[45,49]$. The implementation of these steps addresses the abovementioned three prerequisites for vulnerability / resilience assessment and hence leads to qualitative structural insights into the food system' vulnerability/resilience as presented in Figure 1. Quantitative analysis of system behavior when exposed to disturbances would require a fully specified computer simulation model and is beyond the scope of this paper.
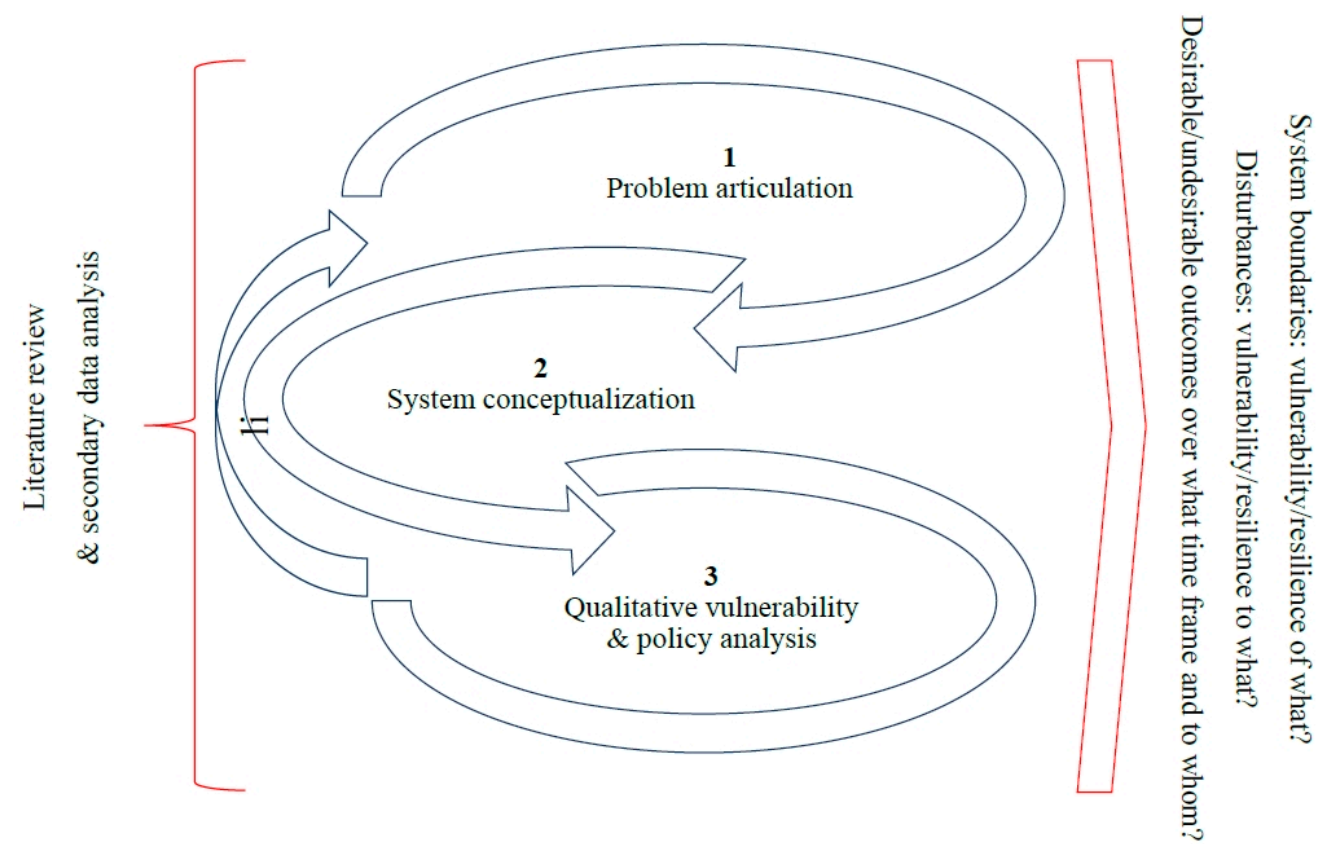

Figure 1. Three iterative methodological steps inspired by system dynamics approach.

The starting point of a system dynamics analysis is the identification of the dynamic problem at stake, that is, the pattern of behavior of the system's outcome of interest, unfolding over time, which shows how the problem arose and how it might evolve in the future [15,45,49]. The initial articulation of the dynamic problem predetermines the system's boundary and the scope of the iterative modeling effort.

To define the dynamic problem in our study and accordingly select the boundary of the modelled food system we analyzed relevant literature and time series of secondary data. Prior to an in-depth search in electronic databases, a general Google Scholar search was run to gather key documents. These papers were used to collect terms and phrases pertaining to the performance of conventional and organic farming in relation to their contribution to sustainable development as well as drivers 
of change influencing the food system in general, and of agricultural production in particular. Based on the terms and phrases we conducted an in-depth search from November 2015 to February 2016 without any restrictions on publication dates to ensure that the broadest set of data could be captured, yet with imposed limitation to English language publications only. The search strategy was applied to four databases: Web of Science (Thomson Reuters, New York, NY, USA), Scopus (Elsevier, Amsterdam, The Netherlands), ScienceDirect (Elsevier, Amsterdam, The Netherlands) and Organic E-prints (International Centre for Research in Organic Food Systems, Tjele, Denmark). In addition, we searched relevant organizational websites (e.g., European Commission, International Federation of Organic Agriculture Movement EU, Food and Agriculture Organization) in order to capture the grey literature. Reference lists of included publications were also hand-searched for additional relevant studies. The content of the pertinent papers was then manually reviewed with support of automatic word frequency and text search queries in NVivo11 ${ }^{\circledR}$ (QSR International, Melbourne, Australia) (a software for qualitative data analysis) to elicit a list of key indicative outcomes of the European food systems based on conventional and/or organic agriculture along with related internal and external variables that are relevant for the subsequent analytical steps. The insights from literature and additional analyses of time series data obtained from EUROSTAT, FAOSTAT and FADN, allowed us to articulate the dynamic problem by specifying the several reference modes of historically observed trends in selected indicative outcomes of the European food system as well as of their desirable and undesirable developments in the face of disturbances. The analysis was conducted on a selection of outcomes being a simplified representation of the European food system's performance from different stakeholders' perspectives (e.g., price for consumer, profits for producers, etc.). We focused on the selective list of indicative outcomes to demonstrate the way in which the system dynamics approach can be used to study synergies and trade-offs in outcomes relevant for different stakeholders. For a comprehensive analysis many more outcomes delivered by the European food system and valued by various stakeholders would have to be further diversified.

Once the dynamic problem has been articulated over an appropriate time horizon, system dynamics modelers specify the model boundary by conceptualizing the system. The boundary of a system is defined in a causal rather than in a geographical way. It implies that system dynamists look for processes that explain observed or anticipated problematic behavior (the dynamic problem), irrespective of where these processes unfold. In system dynamics language, the modelers formulate a theory, called a dynamic hypothesis, which provides an endogenous explanation of the dynamics characterizing the problem at stake in terms of the underlying causal structure of the system. It is a hypothesis as it is always an interim, working theory, subject to reconsideration or abandonment as the knowledge base about the real world develops $[45,49]$. The concentration on endogenous explanations does not mean that exogenous variables are excluded from the model. They are included in models, but each of the candidate for an exogenous variable is carefully examined, to determine whether there is any relevant feedback from the endogenous variables to the candidate. If so, the boundary of the model is extended and the candidate exogenous variable is modelled endogenously [45].

To communicate the system conceptualization a variety of tools can be used. These range from qualitative structural thinking tools (e.g., causal loop diagrams, stock and flow maps), which visually represent different types of variables and their interconnectedness, to operational tools, which express relationships between variables in terms of mathematical equations [15].

In our study, the development of dynamic hypothesis started with insights from the Sustainability Institute [64]. Further, the dynamic hypothesis was enriched with internal and external variables and the associated causal connections elicited from the in-depth literature review, analyzed time series data, theory and general knowledge. Guided by the dynamic problem, we conceptualized the European food system in the form of causal loop diagram drawn in Vensim DSS ${ }^{\circledR}$ (Ventana Systems Inc., Harvard, United States) (i.e., software for system dynamics modelling), in which we marked important feedback processes forming the endogenous explanation. Specifically, we built the system's internal causal structure by tracing from the previously selected indicative food system outcomes 
(i.e., of which dynamic behavior was considered problematic) outward along the chains of cause and effect, variable-by-variable, rather than from system boundary inward. In developing our dynamic hypothesis we did not aim at explaining all possible dimensions of the food system outcomes. Instead, we focused on the key dimensions, represented by the selected indicative outcomes of the European food system, to exemplify how system dynamics structural thinking tools can be used to study complex food system issues.

Arrows represent the causal links between variables, which indicate both the direction of causality and whether the variables change in the same-a positive link (+)—or in the opposite-a negative link (-)-direction (Figure 2). For example, if price is a cause and supply is an effect, a positive link indicates that, ceteris paribus, an increase in price leads to an increase in supply. If, on the other hand, supply is a cause and price is an effect, a negative link means that, all else equal, an increase in supply causes a decrease in price or vice versa a decrease in supply causes an increase in price.

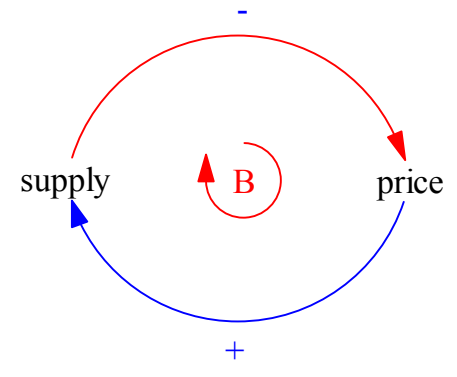

(a)

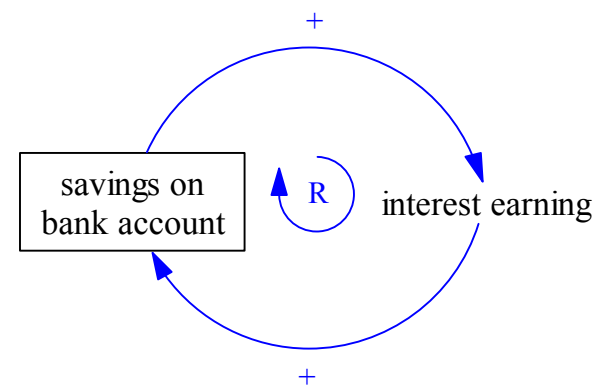

(b)

Figure 2. Indication of causal links, feedback loops and their nature: (a) balancing loop (B); (b) reinforcing loop (R) with signified stock (rectangle) and delay (crossing the causal link arrow).

When a feedback loop arises around two or more variables, we classify it either as a balancing (B; stabilizing, negative; Figure 2a) or a reinforcing ( $R$; amplifying, positive; Figure 2b) feedback loop. To determine the polarity of the loops we trace the effect of change in one of the variables as it propagates around the loop. The classification rule is that if the feedback loop effect reinforces or amplifies the original change, it is a reinforcing loop (e.g., the more savings we have on a bank account, the more interest we earn and in turn the more savings we accumulate); if it counteracts or opposes the original change, it is a balancing loop (e.g., the higher the supply, the lower the price and in turn the lower the supply) [45,49]. Reinforcing are sources of growth, explosion, erosion, and collapse in systems. Balancing loops are self-correcting. For clearer and more insightful analysis, we also indicated in the causal loop diagrams important stocks in rectangles (Figure 2b). Stocks are accumulations, which characterize the state of the system and generate the information upon which decisions and actions are based. They create also inertia in systems that could either be source of disequilibrium dynamics (i.e., instability and oscillations) or filter out unwanted variability [45]. Other delays and flows are also inherent in the structural diagrams, but for readability purposes we did not signify them in any special form.

Once internal structure and feedback processes in the European food system that determine its outcomes were formulated, the resulting causal loop diagram guided the identification of entry points that expose the system to external drivers of change. Finally, we examined the systemic impacts of the internal processes and external unanticipated disturbances on the outcomes of the food system to assess qualitatively both (1) vulnerabilities of the European food systems and (2) the potential of organic farming to reduce the vulnerabilities and enhance resilience of the system. We assessed the direction of the change in the food system's outcomes that internal processes and unexpected disturbances cause. Specifically, we analyzed how the disturbances could be either intensified or reduced throughout the system internal structure and change its outcomes. 
By formulation of the internal causal structure and the identification of the external disturbances we did not aim to capture the complete, real, yet only vaguely understood European food system as a SES. Alternatively, we illustrate how system dynamics structural thinking tools can be used to study where complex food systems might be vulnerable to external disturbance and how these disturbances are transmitted throughout the internal feedback structure; more generally what kind of insights can result from taking such an approach and how it addresses some of the challenges involved in SES modelling.

\section{Problem Articulation: Boundary Selection}

Given the definition of vulnerability above, we frame the dynamic problem as the concern that the European food system when subjected to disturbances of different nature and origin would be unable to withstand them and hence cause its outcomes to considerably or permanently diverge from their desired level. Ericksen [37,39] distinguishes three groups of outcomes that can indicate vulnerability of the food system, namely failure to provide FNS as well as collapse of environmental and socio-economic welfare. The prevailing European food system, which is based on conventional agriculture, continuously faces a trifold challenge of reconciling FNS, viability of rural societies (socio-economic welfare) and sustainable management of the EU's natural land-based resources (environmental welfare) $[4,8,65]$.

In the following subsections we analyze the trifold challenge for policymaking in terms of historical trends in selected indicative outcomes that the European food system delivers. Table 1 summarizes our findings and outlines the desirable and undesirable trends in the outcomes that could result from an exposure of the system to shocks and stresses. These trends serve as reference modes to which we refer back throughout the following vulnerability analysis.

Table 1. Summary of historically observed trends * in indicative outcomes of the European food system along with their desired/undesired trends in the face of disturbances.

\begin{tabular}{|c|c|c|c|c|}
\hline Indicative Outcome & $\begin{array}{c}\text { Observed } \\
\text { Trend }^{1} \\
\end{array}$ & $\begin{array}{c}\text { Desirable } \\
\text { Trend }^{1} \\
\end{array}$ & $\begin{array}{c}\text { Undesirable } \\
\text { Trend }^{1} \\
\end{array}$ & $\mathbf{V} / \mathbf{R}^{2}$ \\
\hline \multicolumn{5}{|l|}{ Food and nutrition security } \\
\hline \multicolumn{5}{|l|}{ Food production } \\
\hline \multicolumn{5}{|l|}{ Yield } \\
\hline \multicolumn{5}{|l|}{ Price of food ${ }^{3}$} \\
\hline \multicolumn{5}{|l|}{ Socio-economic welfare } \\
\hline \multicolumn{5}{|l|}{ Profits ${ }^{4,5}$} \\
\hline \multicolumn{5}{|l|}{ Environmental welfare } \\
\hline Natural resource condition & & & & - \\
\hline
\end{tabular}

* Time range of the historically observed trends are indicated in the text of the Sections $3.1-3.3 ;{ }^{1}$ arrow indicates direction of trend in the particular outcome over time; ${ }^{2}$ qualitative assessment of vulnerability $(\mathrm{V}) /$ resilience (R) to the current impacts of driving forces, where (-) signifies vulnerability, $(+)$ signifies resilience; ${ }^{3}$ consumer perspective; ${ }^{4}$ producer perspective; ${ }^{5}$ profits are expressed at farm level and due to data availability proxied by farm income defined by the European Commission as the farm net value added (FNVA) per annual work unit (AWU) calculated as the sum of total production value plus direct payments minus intermediate consumption and depreciation.

\subsection{Food and Nutrition Security}

In the 1950s-1960s European food producers were primarily concerned with the quantity of foods they needed to supply to overcome the post-war shortages in food availability [65-67]. As a result, food production has experienced a leap forward, which has been attributed mainly to yield improvements rather than expansion of agricultural land. The story of English wheat is emblematic for the European context. It took nearly 1000 years for wheat yields to increase from 0.5 to $2 \mathrm{t} / \mathrm{ha}$, but only 40 years 
to climb from 2 to $6 \mathrm{t} / \mathrm{ha}$ [2]. Simultaneously, despite the inherent tendency of agri-food markets to be volatile, the agricultural commodity prices and related food prices have exhibited a rather steady pattern of decline until about a decade ago. Accordingly, from the perspective of European consumers the food system has been uninterruptedly delivering desirable FNS outcomes. Food per each European has been available in surplus-from around $3000 \mathrm{kcal} /$ day in the $1960 \mathrm{~s}$ to over $3400 \mathrm{kcal} /$ day in the 21st century in comparison with the needed 2000-2500 kcal/capita/day-and accessible at relatively low prices $[1-3,68-70]$.

Yet within the new millennium several undesirable trends in crop yields and prices have emerged. The crop yields in some European regions (e.g., wheat in Northwest Europe or maize in South Europe) have reached or moved close to their plateaus. This implies that the yields have not increased for long periods of time following an earlier period of desired steady linear increase and thus raises concerns over future food availability [71,72]. As regards the prices of agricultural commodities and food, their volatility has increased in the last decade. More specifically, sharp increases in food prices in 2007-2008 and 2010-2011 were followed by recurring periods of often severe price depressions. The high volatility in prices has created an uncertain environment with many undesirable consequences for consumers' access to food. The price hikes caused a rapid increase in consumer food prices, which reduced average EU household purchasing power by around one percent. Low income households (especially the 16\% of EU citizens who live below the poverty line) were hit even harder [73-75].

Furthermore, despite increasing food availability Europe has not managed to guarantee FNS for all citizens. About $10 \%$ of the European households have been persistently unable to access meat or a vegetarian equivalent every second day - an amount generally recommended in European dietary guidelines [75]. At the same time, the proportion of overweight or obese people has continuously increased to reach over $50 \%$ in 2010 [76]. Although both of these undesirable trends are more political and distributional problems rather than agricultural issues per se and hence their in-depth analysis remains beyond the scope of our study, they indicate important failures in the socio-economic organization of food production and downstream food system activities.

\subsection{Socio-Economic Welfare}

FNS and consumers are only one side of the food system. On the other side are the food producers, in a broader sense rural communities, and their viability. While the increase in yields has brought benefits to both consumers and producers, the decline in prices of agriculture commodities has been undesirable for the latter. Accounting for inflation, from 1960s to 2005 European farmers experienced almost incessant (i.e., as one price peak in particular stands out-the so-called world food crisis of the 1970s) real price declines in output and input prices, but with the former decreasing faster. Since then the trend in input prices has reverted and they started to increase, further widening the gap between input and output prices $[77,78]$. This cost-price squeeze has caused an undesirable decline in the realized profits from farm operations and threatened the farm's viability in the long term.

The widening gap between output and input prices has been counterbalanced by significant gains in labor productivity achieved due to structural changes in the EU agricultural sector over the last several decades. The adjustments in structure have been manifested by, inter alia, reduction in farm labor, decrease in the number of farms and increase in the average farm size. To illustrate these trends, from 2002 to 2010 the agricultural labor input in the EU decreased by as much as $32 \%$ (a drop of 4.8 million full-time equivalent jobs), while between the 2005 and 2013 the annual average rate of decline in the number of agriculture holdings stood at $-3.7 \%$ and the average size of each farm in EU-27 rose in terms of hectares from 11.9 to 16.1 as well as in terms of the economic size expressed in European Size Units (ESU) [78-81].

Although during the last several decades the increasing labor productivity have offset the undesirable trend in input and output prices, taking into account the total costs for own and other factors of production (land, labor, capital) still many of the European farms have remained unprofitable with market revenues alone [80-83]. To this end, since the early 1960s subsidies in different forms 
(i.e., within the years there was a gradual shift from price support to direct payments), have played an increasing role in farm profits [78,80-83]. As a result, the average dependence of farm profits on subsidies in the EU is now as high as 58\% [83]. Moreover, in recent years the gains in labor productivity have been increasingly insufficient to compensate for the growing cost-price squeeze and the farm profits have become volatile and hence created a high level of uncertainty among food producers [78,84-86].

\subsection{Environmental Welfare}

Farmers represent only around 5\% of the European Union's (EU's) working population, yet they manage over $40 \%$ of the EU's land area, and generate important impacts on the environment [87]. Hence in addition to FNS and other socio-economic welfare, environmental welfare is of great importance as both a condition for and an outcome of applied agriculture practices.

Over the past decades, the loss of traditional farming to intensive agriculture has contributed to the transgression of a number of critical planetary boundaries [88,89]. Inappropriate agricultural practices and land use have been responsible for adverse impacts on natural resources condition such as pollution of soil, water and air, fragmentation of habitats and loss of biodiversity. The reforms of the CAP in the 1990s, 2003 and 2008 have increasingly integrated environmental protection measures, including obligatory crop rotation, grassland maintenance, and more specific agri-environment measures, aimed at climate change mitigation and biodiversity conservation. In the latest CAP reform in 2010, even $30 \%$ of direct payments to farmers ("Pillar 1") were to become conditional on compliance with "greening measures" [90]. However, during the negotiations the new environmental prescriptions were so diluted, that most farmers are exempted from implementing them and they concern merely $50 \%$ of the EU farmland [91]. Effectively, the agro-environmental measures have brought about some improvements such as decreasing GHG emissions and pesticide use [91,92]. However, according to many academics and stakeholders these improvements have not been sufficient [91-95]. European agriculture still depends highly on external inputs, intensifies and specializes or abandons semi-natural grassland in less productive or accessible regions [91]. Consequently undesirable environmental outcomes like exceedance of nutrients, diffuse pollution to water and dramatic loss of biodiversity persist, further diminishing ecosystems' resilience [91]. More efforts are called for to balance food production and the environment $[91,94,95]$.

\subsection{Signs of Vulnerabilities and Resilience}

European food production-one of the most important FNS outcomes-has been remarkably resilient to the impacts of distinct drivers of change over the last decades (Table 1). However, much of the food had been produced during a period of successful regional cooperation and supportive political environment, relatively stable climate, when farms were predominantly small-scale and diverse, natural resources appeared abundant and the human population was considerably smaller. Besides, despite the abundance of food production, apparently too much of the wrong kind of food at the wrong price has been provided, as the double burden of malnutrition (i.e., undernutrition and overweight) has continued in the EU.

A comparison of the observed trends in the remaining indicative outcomes-i.e., agriculture yield, price of food, profits, natural resources condition-with their desired levels, reveals emerging signs of the European food system's vulnerabilities to disturbances that have been at play so far (Table 1). The productivity of the current food system has come at the expenses of our natural and human resources. This poses severe risks to its continuity in delivering the fundamental FNS outcomes.

To conclude the analysis of indicative food system outcomes over time, it seems that the improvement of some FNS outcomes in the last decades have come at the expense of other food system outcomes and that the European food system is gradually becoming more vulnerable to a wide range of disturbances. If the undesirable developments continue, the existing vulnerabilities 
of the food system might be further exacerbated or give rise to new vulnerabilities endangering the food production.

\section{System Conceptualization: Internal Processes and External Disturbances}

Many processes underlie the trends described in Section 3. In this section, we adopt a feedback perspective and describe the underlying causal structure of the European food system likely to be generating the problematic trends. The structure is composed of several reinforcing feedback processes-mechanization (R1a), intensification (R1b) as well as efficiency maximization (R5)-that explain why food production grows regardless the direction of change in profits realized by food producers. When profits rise, food producers (re)invest in machinery and external inputs to increase food production, whereas when profits fall, food producers feel pressure to reduce production costs by maximizing efficiency and hence again increase food production using equal or even less inputs. Further, the central processes of mechanization, intensification and efficiency maximization are linked to other feedback loops of reinforcing (i.e., labor reduction (R1c), compensation for degraded natural resources with external inputs (R2), organization of food production (R3), substitution of tacit with standardized knowledge (R4)) as well as balancing (i.e., degradation of natural resources (B2), regeneration of natural resources (B2), loss of tacit knowledge (B3), supply (B4) demand (B5), trade (B6), market expansion (B7), cost minimization (B8)) nature. The interconnected feedback structure relates food production to other FNS, socio-economic and environmental outcomes. Based on this integrated feedback structure we explain how the ever rising food production emerges from within the same dynamics as the mounting pressures on human and natural resources that make the food production possible in the first place. Subsequently, we also identify entry points for external disturbances to which the food system might be exposed.

\subsection{Internal Causal Structure Driving the European Food System}

Under conditions of high or rising profits, mechanization and intensification lead to growth in food production (Figure 3). The structure of causes and effects linked together in a set of reinforcing feedback loops (Figure 3) - mechanization (R1a), intensification (R1b) and labor reduction (R1c)—operate in every capitalist market system. Food producers, having profit maximization as a goal, (re)invest in food producing inputs-land, labor (R1c, Figure 3), machinery (R1a, Figure 3) and external inputs (R1b, Figure 3) like fertilizers, plant protection products, seeds, feed, antibiotics, hormones, etc. The (re)investment is encouraged also by political and financial commitment of the EU to the agri-food industry (e.g., subsidies in different forms: direct payments, investment grants, intervention buying, private storage aid or export refunds, etc.). Explicitly, with the subsidies going into agriculture, food producers have both the security and the financial resources to (re)invest in production inputs.

The more inputs are used, ceteris paribus, the more output per hectare (or per animal), i.e., yield, can be achieved. In turn, multiplying the crop (or animal) yield by the limited amount of land area (or the number of animals) determines the food production that flows into the stock of food available for consumption. Food production, if sold on market, brings the producers profits. A share of the profits is reinvested in new production inputs, which are then used to increase the amount of food produced for sale. As long as profits are above breakeven point, implying that food producers are able to cover incurred production costs by received revenues (including subsidies) earning an income comparable to the rest of the economy, the reinforcing feedback loops-R1a, R1b, R1c (Figure 3)-function in the food system and lead to a boost in food production.

Yet having a limited budget and a goal of maximizing profits, the investment decision on 'what' and 'how' to produce involves relevant trade-offs and thus is not straightforward. As regards 'what' to produce, shifts between crop and animal production (not shown in Figure 3 for clarity reasons) result from changes in relative production profitability and consumption patterns of the population [41]. For instance, a growing demand for animal-based food products increases the attractiveness of animal production. Hence, food producers allocate more land and other production 
inputs to animal production at the expense of crop production [41]. Similar tradeoffs occur when considering agricultural production for food and for other uses than food like biofuels, textiles, etc.

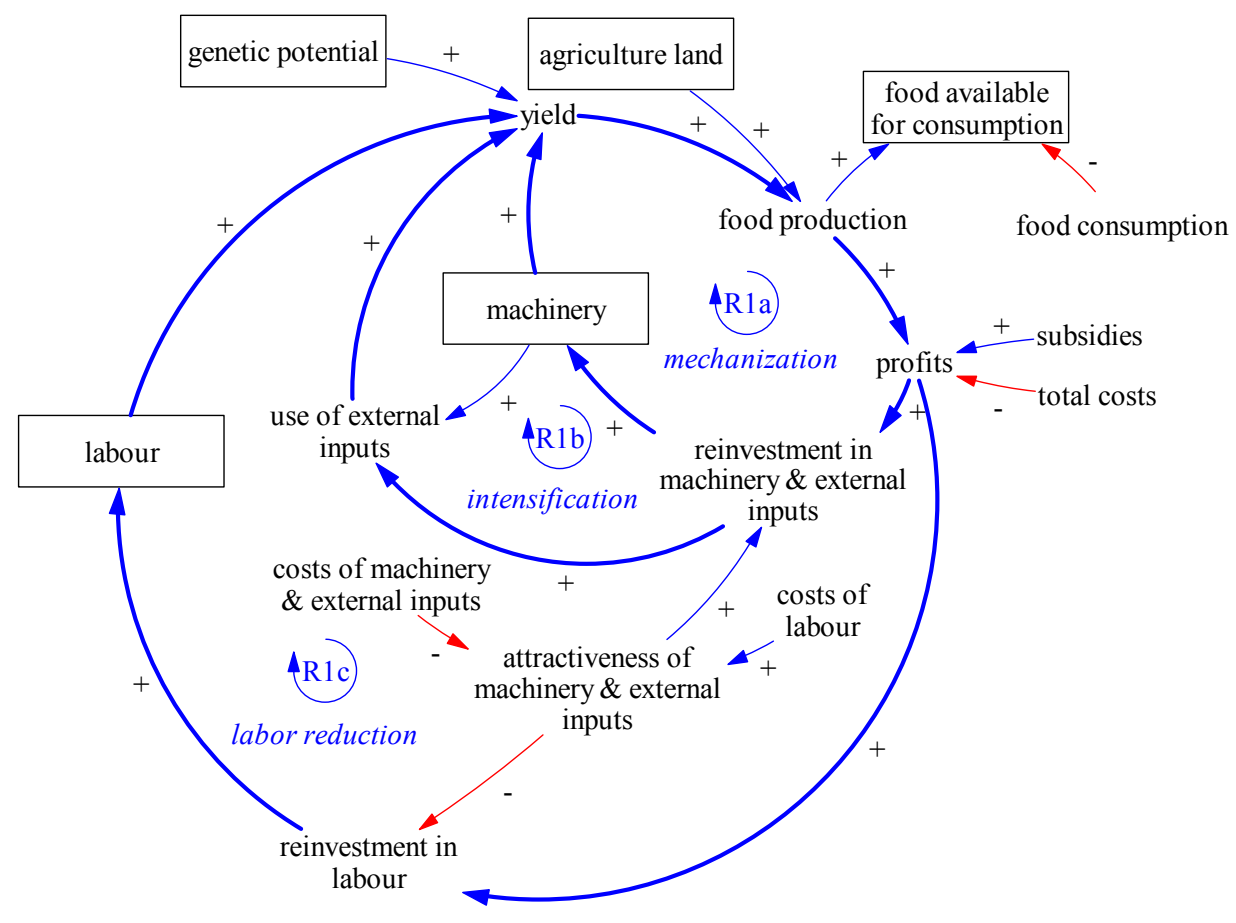

Figure 3. Causal loop diagram representing mechanization and intensification reinforcing feedback loops (respectively R1a, R1b) driving food production growth under conditions of rising profits; some links are omitted for visual clarity.

When deciding "how" to produce, no matter whether this concerns crop or animal production (or other uses), to a certain extent labor can be substituted with machinery and external inputs. The feedback mechanism in Figure 3 shows that when fossil fuel and other external inputs are available and inexpensive, there is a strong incentive to invest and use diesel-powered machinery and off-farm sourced inputs instead of labor to increase yields $[2,9,10,96,97]$. In other words, higher costs of labor increase the attractiveness of investing in and using machinery and external inputs instead. The success of machinery and external inputs in delivering higher yields, translating into higher food production and accordingly higher profits, strengthens itself leading to further mechanization (R1a, Figure 3) and intensification (R1b, Figure 3) of farm practices. Simultaneously, because of decreasing reinvestment in labor and hence its replacement with machinery and external inputs, the stock of labor is forced into a reinforcing downward spiral that gradually leads to labor reduction (R1c, Figure 3) [79,96,97].

Food production is embedded in ecosystems, implying that it is based on the condition of natural resources such as soil, water, air, biodiversity, nutrients and fossil fuels (Figure 4). As the natural resource base is limited, food production cannot grow infinitely. The worse the conditions of natural resources, the lower yield can be achieved and/or the less agricultural land is available for food production. The flows-degradation (outflow) and regeneration (inflow) - that influence the stock of natural resources are determined, among other things, by the implemented management of agroecosystems (i.e., the 'what' and 'how' to produce). Intensive food production practices that depend on use of external inputs tend to degrade the productive natural resources by their overexploitation (e.g., phosphate rock [98-100], fossil fuels [101,102], etc.) and pollution (e.g., nutrient leaching [88], GHG emissions [103], etc.) [7,8,104-107]. For instance, the stronger the reinforcing feedback loops driving use of diesel-powered machinery (R1a, Figure 3) and synthetic nitrogen fertilizers (R1b, Figure 3), the more of the non-renewable fossil fuels [108] are exploited and the more GHG are emitted to 
the atmosphere [109]. Likewise, the more pesticides are used to combat pests and diseases, the lower is the biodiversity and biological control potential on farmland $[110,111]$. These practices increase the rate of degradation and translate thus into a more degraded natural resource base. The degradation rate increases with increasing animal production, as animal-based food products are particularly resource-intensive $[112,113]$. At the same time, in intensive food production systems practices that treat natural resources in a more regenerative way are minimal or even none. As the outflow (degradation) of natural resources is higher than the inflow (regeneration) of natural resources, then the condition of natural resources worsens, jeopardizing the food production.

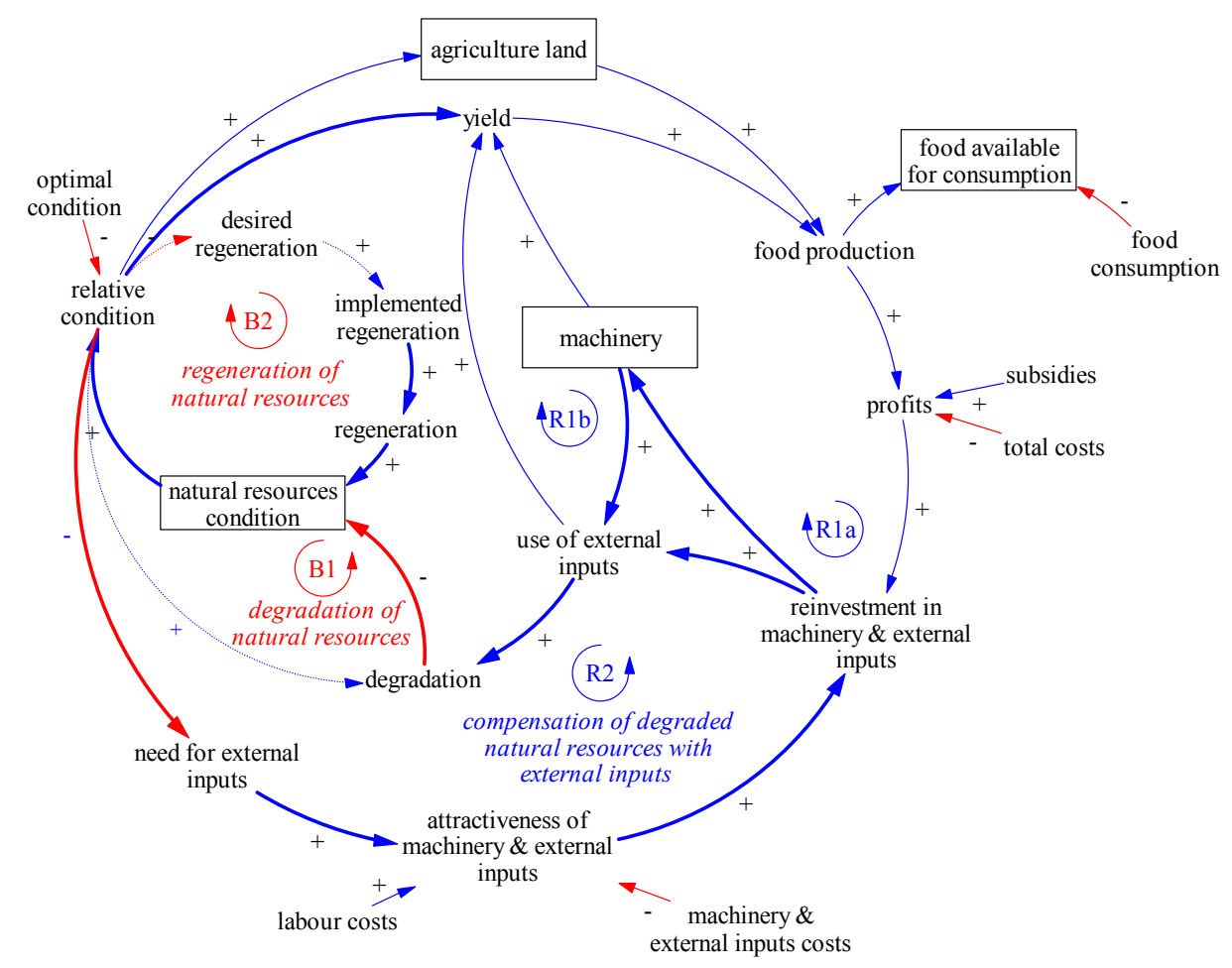

Figure 4. Causal loop diagram representing the relationship between food production and natural resources condition (B1, B2, R2); some links are omitted for visual clarity.

There are two balancing feedback loops that regulate degradation (B1, Figure 4) and regeneration (B2, Figure 4) of natural resources. The goal of the two balancing feedback loops is to maintain the condition of natural resources in a stable state. The balancing feedback loop B1 (Figure 4) sets limits to overuse or pollution (degradation) of natural resources as their condition worsens. The limit is signaled to food producers through, for instance, declining yield or rising costs of acquiring non-renewable natural resources (e.g., phosphate rock, fossil fuels) when they become scarce. However, the signal is often either missing or too weak and too delayed for food producers to notice it and implement on time more environmentally benign practices that decrease degradation (e.g., by reduced use of external inputs) and/or increase regeneration (signified with dashed lines in Figure 4) $[11,15,64]$. The longer the food producers do not recognize the worsening condition of natural resources and do not desire and effectively implement regenerative practices, the lower is the actual regeneration. With insufficient regeneration, all else equal, the conditions of natural resources move farther away from an optimal level, which should translate into increased need for regenerating natural resources (desired regeneration). However, because of the distorted flow of information about the relative condition of the natural resources, the desired and accordingly implemented regeneration is limited. That is, the desired regeneration is underestimated and impedes making informed decisions on implementation of appropriate food production practices. 
Furthermore, external inputs can imitate some functions of the food producing natural resources (at least in the short-term). This feature allows food producers to substitute natural resources with external inputs in food production, when the condition of the former deteriorates [15,114]. As a result, food producers fall into a reinforcing spiral of compensating for the degraded natural resources with the application of external inputs (R2, Figure 4) rather than implementation of regenerative practices, which, in turn, further worsens the condition of natural resources. The reinforcing feedback loop driving substitution of natural resources with external inputs to produce food is a vicious circle that locks farmers into dependence on the use of external inputs.

Food producers require knowledge to know how to best organize food production (Figure 5) (i.e., to combine food production inputs with ecosystems to achieve the highest potential yield holding the costs constant). According to theorists, knowledge is perhaps the most relevant economic resource and learning the most important process [115]. In principle, the more one has of production inputs and knowledge, the more can be produced. Hence, the growth in food production is driven by accumulating inputs (e.g., land, labor, machinery, external inputs, etc.) (R1a, R1b, R1c, Figure 3) as well as the technical, agronomic knowledge that drives organization of food production processes (R3, Figure 5) [116].

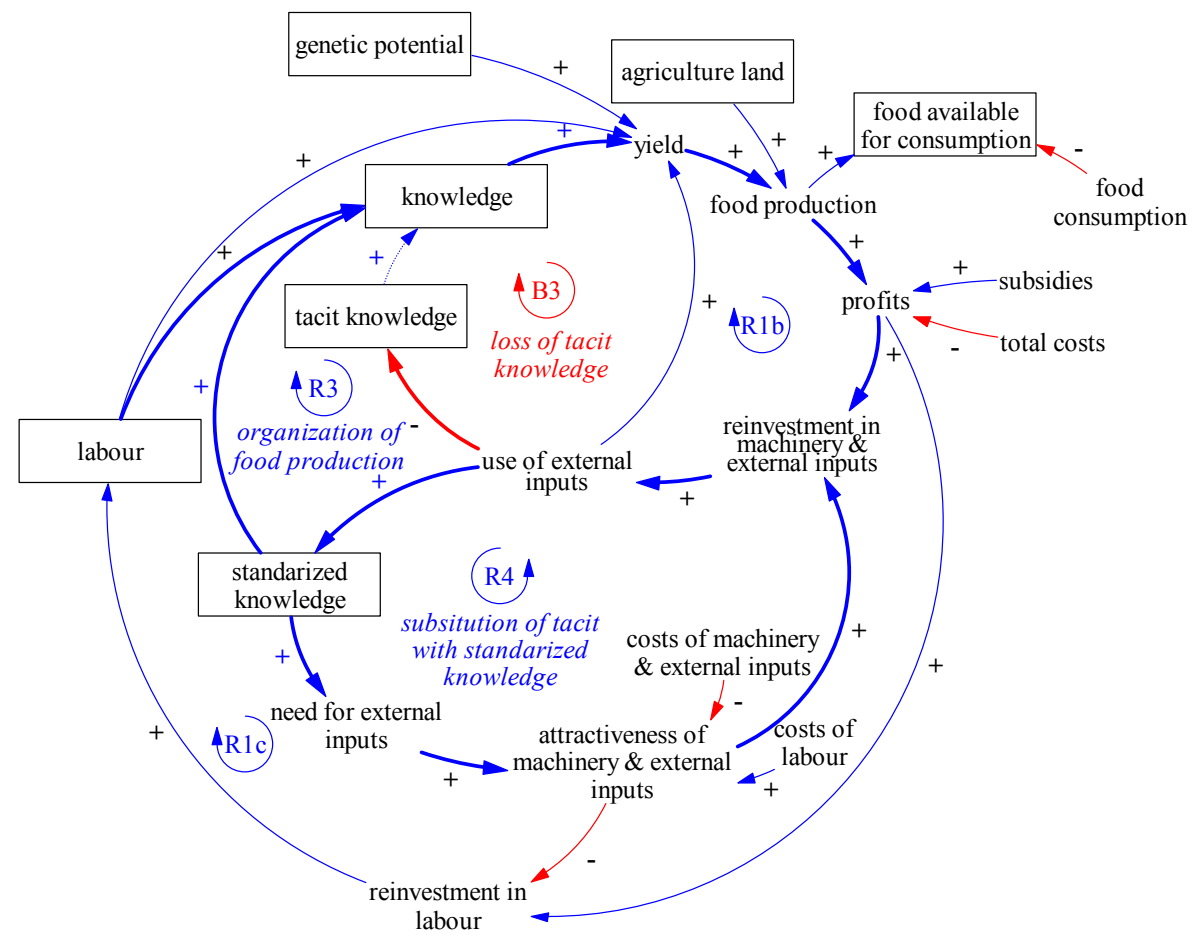

Figure 5. Causal loop diagram representing the relationship between food production and knowledge (B3, R4); some links are omitted for visual clarity.

Food producers gather knowledge while performing their activities and because of new learnings. Knowledge of food producers is a combination of tacit (or local) knowledge with standardized (or codified) knowledge [117]. The more knowledge of tacit and/or standardized nature food producers have, the stock of total knowledge increases. As a result food producers (at least theoretically) are able to better organize food production and realize higher yield (R3, Figure 5).

In contrast to standardized knowledge, tacit knowledge of food producers implies an intimate knowledge of their landholding, its composition, fertility and so on, acquired through food producing practices (e.g., rotation, ploughing, etc.). The tacit knowledge is localized as it is closely tied to local ecosystem in which food production takes place. For instance, while the same principles of growing crops are widespread, tacit knowledge allows food producers to apply these principles differently 
in different local conditions and hence produce better results. With the widespread application of external inputs (intensification, R1b, Figure 3), which need not to be adapted to local circumstances as simple standardized instructions on their use provided usually by input industry are sufficient for food producers to achieve desired yield, the relationship between food producers and local ecosystems is disrupted. Accordingly, the stock of tacit knowledge required to manage the local ecosystems fades away, whereas uniform and spatially standardized knowledge accompanying use of external inputs builds up and replaces the former type of knowledge [117]. The function of the balancing feedback loop B3 (Figure 5) is to signalize the loss of tacit knowledge through decreasing yield. Yet the warning sign is hugely disregarded by food producers or masked by the large and powerful institutions which lie upstream (and downstream) of the farm [11,117].

The longer the importance of accumulating tacit knowledge for achieving better yield in the long-term remains unnoticed by food producers, the substitution of tacit knowledge with standardized knowledge (R4, Figure 5) progresses. This development locks food producers into a vicious circle (R4, Figure 5) of increasing reliance on the use of external inputs [117].

Produced food is supplied on an agri-food market, which is a medium that allows consumers to access food (Figure 6). On a competitive agri-food market, price balances food production with food consumption. The functioning of such a market is characterized by the interplay between two balancing feedback loops of supply (B4, Figure 6) and demand (B5, Figure 6), both of which in a globalized setting are influenced by trade arrangements (B6, Figure 6).

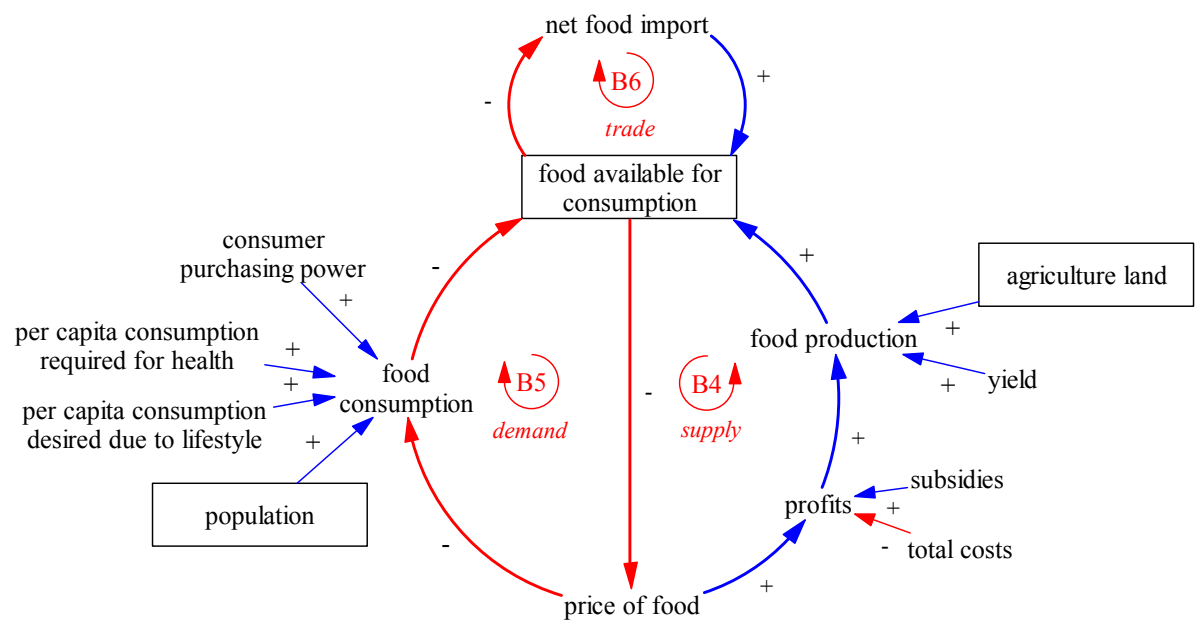

Figure 6. Causal loop diagram representing competitive market structure characterized by interplay between two balancing feedback loops of supply (B4) and demand (B5), both of which in a globalized setting are influenced by trade (B6); some links are omitted for visual clarity.

On the supply side (B4, Figure 6), a large number of food producers compete with each other. Specifically, producers reinvest (R1a, R1b, R1c, Figure 3) and produce food, increasing the amount of food available for consumption. Profits are realized when the amount of revenues gained from producing food exceeds the incurred production costs. As revenue is the product of the volume of produced food being sold and the price of the food, the higher the production and/or the higher price, ceteris paribus, the more profits food producers realize. Rising profits encourage existing food producers to reinvest and increase output (food production) as well as attract new entrants to the market. However, greater food production increases the stock of food available for consumption, which in turn, bids the price of food down. Declining price of food, all else equal, diminishes profits and hence discourages food producers from investing in increasing food production (B4, Figure 6).

On the demand side (B5, Figure 6), the population consumes (and wastes) the supplied food according to its purchasing power, dietary requirements for health and desires due to its lifestyle. The lower is the price of food, the more access to food people have and thus the more food is demanded. 
Higher food consumption diminishes the amount of food available for consumption, which translates into, all else equal, higher price of food (B5, Figure 6).

The state of the stock of food available for consumption indicates the balance between food production (as proxy for supply) and food consumption (as proxy for demand). The supply (B4, Figure 6) and demand (B5, Figure 6) balancing feedback loops cause the price of food to adjust until, in the absence of market imperfections and external disturbances, the market reaches an equilibrium characterized by a clearing price at which food production equals food consumption (i.e., the stock of food available for consumption is stable).

In a globalized world, however, in which markets are committed to open trade, there is an additional balancing loop B6 (Figure 6). Food producers export surplus of food production or are confronted with competitive imports, if the domestic food production is insufficient to meet the desired consumption. The imports add to the stock of food available for consumption, putting an additional downward pressure on price, and vice versa in case of exports. Hence, protective measures for reasons of FNS or employment are a natural response of governments.

In case of oversupply, food producers and governments put efforts to expand the market (Figure 7). Most agri-food markets are competitive, but not always perfectly. Market imperfections (caused by, for example, subsidies) add to the tendency to oversupply food relative to demand (i.e., the stock of food available for consumption increases). An extreme example of this phenomenon are the European Union's 'butter mountains and milk lakes' that occurred in the 1990s. As mentioned earlier, the oversupply pushes the price of food downward, reducing revenues and, ceteris paribus, consecutively profits. When the stock of food available for consumption increases, price of food declines and thus profits drop, food producers face pressure to expand the market in order to distribute the surpluses of food. Hence, usually along with governments they try to expand markets by, for instance, storing, exporting (B6, Figure 6), upgrading (e.g., ready-made meals instead of raw food products), advertising, or creating new uses of agricultural products (e.g., bioenergy from food crops). Accordingly, the consumption of food products goes up, reducing the stock of food available for consumption and pushing up the price and profits (B7, Figure 7). In fact, although there is no general consensus on the relative importance of the underlying causes for the 2007-2008 food price increase, the new, stimulated by policies, demand for biofuel feedstocks from grains and oilseeds has been widely cited as one of the major factors explaining the food price boom [118-124].

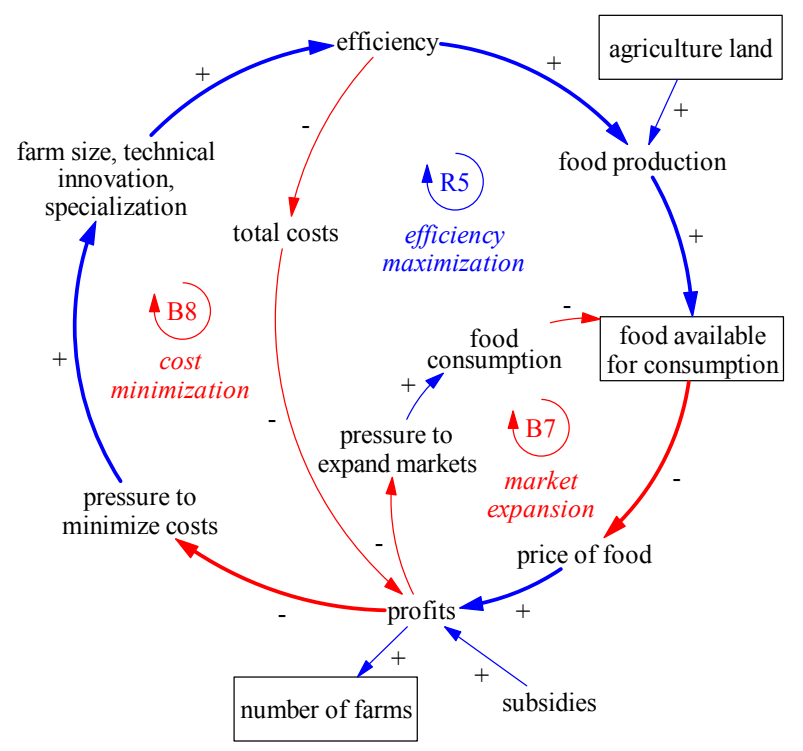

Figure 7. Causal loop diagram representing efficiency maximization reinforcing feedback loop (R5) driving food production growth under conditions of falling profits; some links are omitted for visual clarity. 
However, when there is a general impression that the price of food is likely to rise from additional demand, existing food producers tend to speculate. Hence, they (re)invest in inputs to increase food production (R1a and R1b, Figure 3) in order to maximize profits from the expected price rise when the investment in new production is realized. If the price increase is considerable and progressive, also new producers are attracted to enter the agri-food market. As long as the price has not begun to fall, food producers extrapolate the price trend and are willing to believe that it will continue rising. After a time, depending on the delays involved in expanding production, the overproduction begins to be perceived and the price begins to decline again through the supply balancing feedback loop (B4; Figure 6). Food producers, if possible, rush with their products into agri-food market to avoid greater loss, dramatically worsening the imbalance between demand and supply. Consequently the price of food and producers' profits fall even harder and the agri-food market enters again into crisis.

Under conditions of low or falling profits, efficiency maximization leads to growth in food production (Figure 7). In addition to the amount of food sold, its price and subsidies, profits depend also on total costs incurred during food production. The higher are the total costs of production, the lower are the profits realized by food producers, all else being equal. If both trends-decreasing or stagnating price and growing costs of production-occur concurrently, food producers face a cost-price squeeze that causes profits to drop, farm debt to grow and a general loss of producer power. Food producers usually try to alleviate the undesirable downward pressure on their profits via a number of balancing processes aimed at cost minimization (B8, Figure 7) [70,125-131].

When the profits are negative, many food producers, particularly the small- and medium-scale ones, abandon the industry altogether (Figure 7). Only those food producers remain in the agri-food business that are most efficient and/or have the most optimistic expectations on the future price and costs [45,70,129-135]. This is evident in the declining number of farms. Meanwhile, however, the total number of cultivated hectares of land remains more or less constant. Hence, farm size increases, meaning that overall there are fewer but larger farms. In fact, scale economies along with technical innovations and specialization reinforce each other and are the most common routes to compensate for the falling profits by minimizing costs of food production through improved efficiency (B8, Figure 7) [129,130].

Although profits improve when food producers keep on minimizing costs through achieving higher efficiency (B8, Figure 7), a reinforcing mechanism resulting from efficiency maximization (R5, Figure 7) impedes their efforts. To produce food more efficiently means to produce more food with the same or less production inputs. The usual net result of minimizing costs (B8, Figure 7) and maximizing efficiency (R5, Figure 7) is that globally food production goes up, prices go down, and the realization of profits is again no longer possible even with the lower production costs. Food producers are locked into a vicious circle (R5, Figure 7), in which lower prices of food put a continuous pressure on food producers to minimize costs that forces them to become even more efficient if they are to survive at all. The farmers who lag behind and do not become efficient enough are lost in the price (or even cost-price) squeeze and leave room for the more successful food producers to expand [136].

\subsection{Entry Points for External Disturbances in the European Food System}

In addition to the internal causal structure, the functioning of the European food system is driven by multiple adverse and favorable external disturbances of various origin (e.g., socio-economic, ecological, technological, political etc.) $[1,2,10,47]$. Food system disturbances range from rapid and dramatic shocks (e.g., pest outbreaks, economic and political crises, weather events such as droughts, floods, or storms, fuel shortages, disease pandemics) to slow and moderate stresses (e.g., climate change, urbanization, population growth, changing consumption patterns), which do not function in isolation from one another, but co-occur and interact in many different ways $[39,137,138]$.

In this section, we combine the individual causal loop diagrams from previous Section 4.1 into an integrated causal structure of the European food system to identify entry points that expose the system to external disturbances (Figure 8). 


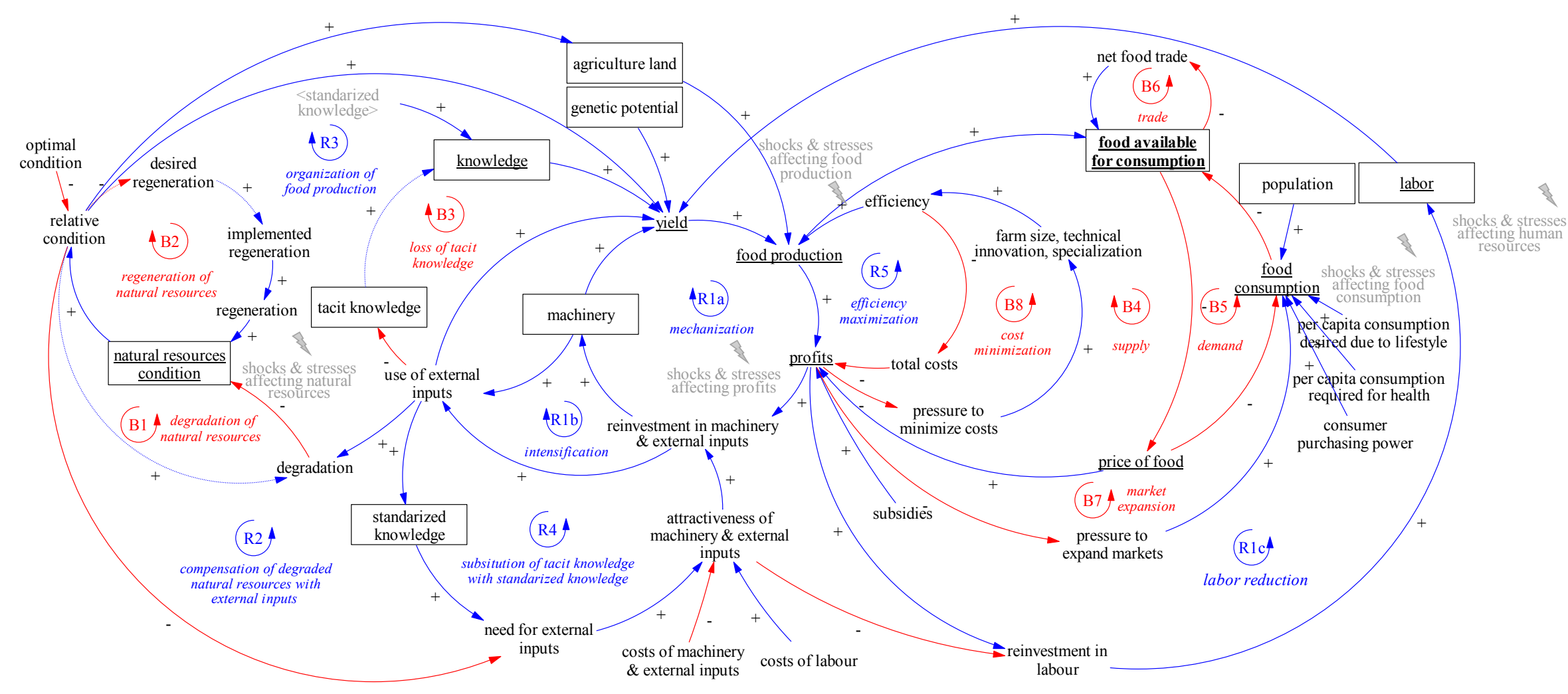

Figure 8. Integrated causal loop diagram of the conventional European food system with indicated exemplar entry points for external drivers of change; underline- - key food system outcomes, grey \& lightning ( ) —examples of entry points for external drivers of change; some links are omitted for visual clarity. 
In principle most of the variables constituting the internal causal structure of the food system could be affected by a range of different shocks and stresses form outside the system. Examples of such entry points for external disturbances include (Figure 8):

- Food production can be affected by unfavorable weather conditions (e.g., severe droughts led to reoccurring famines in Russia) and pest outbreaks (e.g., potato disease caused crop failure that led to Great Irish Famine) that reduce crop yield, livestock diseases (e.g., avian flu or bovine spongiform encephalopathy) that lead to removal of large numbers of animals from the system as well as geopolitical dynamics causing disruptions to supply of external inputs used to maximize crop yield (e.g., phosphorus fertilizer, fossil fuels).

- Profits of food producers can be affected by an economic crisis that causes price of external inputs to increase considerably or become volatile as well as unfavorable political environment that leads to sudden or gradual removal of financial support (e.g., subsidies) for agriculture.

- Natural resource conditions can be affected by urbanization and population pressure that cause loss of agricultural land to other purposes, competition for resources (e.g., water, fossil fuels) from other industries that reduces the amount of natural resources available for food production or climate change impacts that disrupt provision of ecosystem services needed for food production.

- Labor employed in food producing activities can be affected by widespread disease outbreaks that reduce productivity of labor force or even the number of people able to produce food.

- Food consumption can be affected by population growth and ageing, changes in household incomes, changes in dietary patterns as well as routine and habits (e.g., food waste), values and ethical stances of consumers.

The integrated structure presented in Figure 8 allows us not only to identify what shocks and stresses the food system at stake, but also to systemically explore how the disturbances may be conveyed throughout key feedback processes in the food system and generate vulnerabilities. Examples of such pathways are provided in the following Section 5 .

\section{Vulnerability Analysis: Interplay between Internal Causal Structure and External Disturbances}

The analysis of internal causal structure in Section 4 shows how the conventional model of the European food system has been able to deliver ever greater quantities of cheap food. Specifically, increase in food production, despite the direction of change in profits, has been possible due to several strong reinforcing feedback loops that underlie reinvestment in machinery (mechanization, R1a, Figure 3) and external inputs (intensification, R1b, Figure 3) as well as efficiency maximization realized through scale economies, specialization and technological innovations (R5, Figure 7). From the perspective of many consumers these reinforcing feedback loops have been virtuous circles that have allowed them to access food at affordable prices. However, the benefits to consumers have come at a cost. Food producers have experienced the same reinforcing processes as vicious circles that have eroded their profits and involved them into a 'treadmill' where individual food producers must produce ever more just to stay in the agri-food industry $[64,70,136]$. Furthermore, the same strong reinforcing feedback loops have forced the European food system also into a counter-productive behavior and made it vulnerable to external disturbances. First, the reinforcing processes have been accompanied by several balancing feedback loops of which role is potentially to signal and minimize the undesirable socio-economic and environmental outcomes of the food system. However, in most cases the balancing processes have been either too weak or too delayed to do so. As a result, the strong reinforcing feedback loops underlying food production growth have generated numerous unintended negative impacts on human (e.g., reduction of rural employment, loss of knowledge) and natural resources (e.g., loss of biodiversity, soil degradation, pollution of water and air) which themselves are preconditions for food production. Second, they have given rise to two additional strong reinforcing processes-i.e., compensation for the degraded natural resources with the application of external inputs (R2, Figure 4) and substitution of tacit knowledge with standardized knowledge (R3, Figure 5) - that have made food producers 
increasingly reliant on the use of external inputs. Below, we outline five key vulnerabilities that stand out from our analysis of the internal causal structure.

Vulnerability I: Degrading natural resources

The stock of natural resources is a proxy for diversity and thus a kind of a buffer that absorbs ecological disturbances such as weather shocks or plague of pests in the system. Natural resources determine also how many options for adaptation and alternative solutions food producers have. Assuming relatively stable climate and abundance of natural resources, the reinforcing loops driving food production and at the same time degrading natural resources through mechanization (R1a, Figure 3), intensification (R1b, Figure 3) and efficiency maximization (R5, Figure 7) (all of which facilitate monoculture) could be strong, while degradation and regeneration of natural resources (B1, B2, Figure 4) weak and delayed (as they have been so far). However, we now know that the natural resources are finite (or take a lot of time to regenerate) and once they are depleted, food production is not possible anymore, while there will be few (or even no) options for adaptation to this and other disturbances. Especially because implementation of alternative solutions such as low external input practices usually requires a good condition of natural resources to achieve the desired yield without external inputs. Moreover, given that the literature on climate change predicts weather disturbances and pest infestations to become more extreme and more regular, by deteriorating the condition of natural resources food producers reduce ecological resilience of their agroecosystems to these shocks and ultimately endanger food production.

Vulnerability II: Trading tacit with standardized knowledge

Tacit knowledge is necessary for food producers to be able to continuously adapt their practices to changing conditions and thus keep producing enough food. In the conventional European food system strong reinforcing feedback loops that drive intensification (R1b; Figure 3) and efficiency maximization (R5, Figure 7) erode the traditional, local, ecosystem-sensitive (tacit) forms of knowledge and replace it with standardized, codified forms of knowledge. At the same time, the balancing loop (B3, Figure 5), of which role is to minimize the loss of tacit knowledge, is weak as many food producers disregard it. Consequently, the feedback processes reduce the capacity of food producers and the scope of options available for them that are necessary to make autonomous decisions regarding what they produce, how they produce it, and why. Food producers could afford to trade tacit with standardized knowledge for increased output when the conventional model of food system is not exposed to disturbances and works smoothly-producing ever more food at ever lower price with few unnoticeable side effects. However, as the food system moves into a crisis caused by, for instance, visible environmental impacts of conventional food production or consumers' concerns about food quality, the vulnerability of food producers becomes apparent. Food producers would need a lot of time (e.g., in case of crops, several growing seasons) to rebuild the stock of tacit knowledge indispensable for effective implementation of alternative practices and thus achievement of the same or better level of food production.

Vulnerability III: Dependence on external inputs and governmental subsidies

The strong reinforcing feedback loops that drive food production through intensification (R1b, Figure 3) and mechanization (R1a, Figure 3) and concurrently degrade natural resources and erode tacit knowledge, give rise also to two additional strong reinforcing processes through which degraded natural resources are compensated for with external inputs (R2, Figure 4) and tacit knowledge is substituted by standardized knowledge (R4, Figure 5). Both of the latter reinforcing feedback loops are examples of unintended processes that increasingly lock food producers into dependence on external inputs, the companies that provide them, the financial resources needed to purchase them and the capitalist relationships within food production that frame their decisions $[5,139]$. The use of external inputs considerably changes food producing practices as well as agroecosystems in which they are applied. Inter alia, some external inputs give rise to unintended consequences (e.g., weed resistance, pollinator decline) that are then stabilized with new external inputs (e.g., stronger herbicide cocktails). 
This, in turn, reinforces the dependency of food producers on the use of external inputs. The result is that food production is based on a continuous reinvestments in engineered stabilizers rather than tacit knowledge and ecosystems resilience (condition of natural resources). Therefore, if for some reasons (e.g., fossil fuels scarcity, geopolitical tensions, economic crisis) external inputs were not available for food producers: first, it will take a long time for an alternative food production paradigm to become effective (because of, for instance, the need to rebuild the stocks of tacit knowledge and natural resources condition) and second, the outcomes could potentially be far more undesirable than that of a system which never used those stabilizers. Moreover, relying on a limited range of 'stabilizing' external inputs makes the food system particularly vulnerable to disturbances that operate beyond their scope of fixes such as unexpected and non-linear climate change and feedbacks. As high external input systems are capital-intensive, one could think of vulnerability arising from dependence on financial subsidies and the governments that provide them in a similar way.

Vulnerability IV: Latent instability of agri-food markets

When food production is higher than food consumption one might expect that the balancing processes driving the functioning of agri-food markets, i.e., supply (B4, Figure 6), demand (B5, Figure 6) and trade (B6, Figure 6) would equilibrate them. However, many European agri-food markets are imperfect due to governmental support (subsidies) and regulations (e.g., production rules), information and power asymmetries, costs of entry and exit, and inflexibility of natural resources [140-147]. These imperfections either strengthen or weaken the market balancing loops (B4, B5, B6, Figure 6) or create new ones (e.g., market expansion balancing loop B7, Figure 7) that sometimes overwhelm the existing ones, leading to inefficiencies or even failure of markets [45]. For instance, one might expect that in the face of rising food production and falling profits, the food producers would reduce or even cease production. While it is true, that the number of food producers tends to decline over time, the EU within CAP offers subsidies to food producers that weaken the balancing feedback loops on agri-food markets and foster the gain around positive feedback loops that drive food production up. As a result food producers stay in unproductive and saturated markets. In other words, subsidies stabilize the viability of food producers and keep food production high, but also make them increasingly reliant on this form of support and the governments that provide them (see Section 3.2) $[77,83,148,149]$. Furthermore, the balancing loops frequently involve long delays (e.g., length of growing season, duration of transportation and distribution, time to perceive price changes by producers and consumers, etc.), weak responses (e.g., low short-run and high long-run elasticity of demand) or boundedly rational decision making (e.g., market expansion balancing loop B7, Figure 7), that predispose the agri-food markets to persistent disequilibrium and instability [45,150-152]. Disturbances such as sudden removal of subsidies, weather- or pest-related crop failures, increased price volatility, food scandals causing sudden drop in food consumption can stimulate and amplify the latent oscillatory behavior of agri-food markets giving rise to undesirable volatility of price of food and/or profits realized by food producers [118,120,153].

Vulnerability V: Striving for efficiency, while losing resilience

The conventional European food system manages its growth and expansion based on ideas of maximizing efficiency realized through inter alia scale economies, specialization and technological innovations (i.e., balancing loop of cost maximization (B8, Figure 7) that perpetuates the strong reinforcing feedback loop of efficiency maximization (R5, Figure 7)). Food producers across Europe experience effects of these processes in many different ways. Scale economies force many small- and medium-scale food producers out of the agri-food business entirely-evidence through declining number of farms and increasing farm size. This trend along with the strong reinforcing spiral of labor reduction (R1c, Figure 3) translates into increasingly fewer people in society with knowledge and skills needed to produce food (i.e., further decline in the stock of tacit knowledge, Figure 5). Besides, scale economies drive consolidation and reduce the diversity of scale at which food producers operate. 
Specialization is apparent, for instance, in the trend towards a single dominant activity on farms and widespread monocultures. Currently, in the EU almost half of the holdings are specialized in cropping and $27 \%$ in livestock [154]. Accordingly, as the system specializes, the diversity of organizational forms as well as of crops and animals decreases in the food system. Technical innovations (e.g., application of more and more specific fertilizers, herbicides and pesticides and genetic advances) to a great extent are in hands of few multinational corporations [5]. This narrows down sources of technical innovations as well as the choices available for food producers. For instance, commercial seeds and breeds focus on a few traits in a few crops, which forces food producers to base their production activities on them. The three processes seem to favor each other, so that, for instance, the technical innovations (e.g., promotion of agrochemical use, biotechnology, single crop machinery, etc.) are most (costs) beneficial through scale economies and specialization $[5,9,129]$. Common feature of all of these processes is that they increase efficiency, but at the same time decrease diversity of different elements in the food system, while diversity is crucial for absorption of shocks and stresses, adaptation, and alternative solutions $[5,9,47,155]$. Having low diversity in the food system allows disturbances to be augmented in both socio-economic (e.g., food pricing controlled by few) and ecological (e.g., contamination on a single farm can easily effect the entire country) dimensions. Thus, it seems that through strong efficiency maximization loop (R5, Figure 7) food producers trade-off short-term productivity against long-term resilience.

In essence, vulnerabilities in the conventional European food system arise if a disturbance strengthens the reinforcing feedback loops and further weakens or delays the balancing loops. For instance, climate change related shocks such as drought, flood or storm, will likely strengthen the intensification reinforcing feedback loop (R1b, Figure 3) because of yield losses. Yield losses increase the pressure on food producers to produce more, disregarding the balancing loops of natural resources degradation and regeneration (B1, B2 Figure 4), thus further lowering the stock of natural resources condition. When the stock depletes, yield declines, and translates into undesirable outcome of reduced food production and hence food insecurity. Another example is a stress of growing population that demands more resource-intensive animal products (demand side of the agri-food market, B5, Figure 6), which most likely strengthens the efficiency maximization loop in addition to intensification (R1b, Figure 3) and mechanization (R1a, Figure 3) loops. As the population grows and demands more animal products (i.e., per capita consumption due to lifestyle rises, Figure 6), food consumption rises. Food producers feel pressure to produce more of both animals and crops, as part of the crop production is redirected to feed for animals. Yet the amount of agriculture land is limited. Food producers are pressured to intensify as well as maximize efficiency. As a result, the disturbance strengthening the reinforcing feedback loops, propagates throughout the system, exacerbating all the vulnerabilities outlined above.

\section{Policy Analysis: The Potential Role of Organic Farming}

As a whole, the conventional European food system, relying on external inputs and policy stabilizers, reveals resilient features-it provides plentiful and inexpensive food. However, the value judgement of what is resilient or vulnerable to what and over what period of time depends on the beneficiaries. Assessing it through sustainability lenses, we argue that the capitalized, high external input food system is vulnerable to disturbances that operate beyond the system's own boundaries of ontology (i.e., a set of concepts and their relations that are specified in some way), epistemology, or control, such as unanticipated or non-linear climate variability and feedbacks or unpredicted ecological consequences of continuing use of external inputs. Thus, an alternative approach to food system, which does not trade-off long-term resilience for productivity and stability, is called for [5,7-9]. King [16] lists several potential approaches for a resilient food system, including organic and biodynamic farming, permaculture, farmers' markets, community-supported agriculture and community gardens. In Europe organic farming is the fastest growing of all alternatives to the conventional food system, which is regulated at EU level and receives considerable public financial support. However, can organic farming make the European food system more resilient? 
In contrast with the conventional European food system, organic farming is a low external input system, in which organic matter cycles and diversification of crops and animals are key concepts. Many meta-analyses and reviews provide evidence for enhanced environmental impact of the organic farming practices in comparison with the conventional system [21,31,36,156,157]. Thus, organic food producers have the potential to address the vulnerability related to worsening conditions of natural resources. Specifically, they are able to recognize the two balancing loops-natural resource degradation and regeneration (B1 and B2, Figure 4) - and implement practices that strengthen both of them and the important stock of natural resources accumulates, making the system more resilient to disturbances such as climate change. For instance, due to water-holding capacity of soil organic carbon stocks, which is built through common agroecological practices such as diverse and companion cropping, planting green manure and cover crops, and integrating forages and perennials, organically managed farms have been shown to produce higher yields than their conventional counterparts under conditions of severe droughts or excessive rain [158]. In addition, through strategic diversification of crops, organically managed plantations can be also more resilient to pest outbreaks, as commonly a single pest usually damages a particular variety [9].

With regard to trading tacit with standardized knowledge, several studies have shown that organic food producers pay attention to natural cycles in their practices (i.e., balancing loop loss of tacit knowledge gains strength (B3, Figure 5)) and hence accumulate much more tacit knowledge than producers in conventional systems $[117,159]$. In that sense, agroecological practices have potential to lead not only to more natural resources, but build up the human resources as well [117]. Organic food producers may then be better prepared to cope with disturbances over long term.

Organic farming per definition is a low external input system with inter alia diversification and nutrient cycling at its heart. It has, thus, potential to preserve higher stocks of natural resources and tacit knowledge as well as to better recognize and operate the balancing loops (B1, B2, Figure 4; B3, Figure 5). Accordingly, organic food producers may be able to escape from being locked into the dangerous dependence on external inputs (R2, Figure 4; R4, Figure 5).

However, implementation of organic food production principles in practice is diverse and ranges from mere 'input substitution' to fundamental 'system redesign' [160]. This implies that there are organic food producers, of which practices diverge only slightly from conventional practices [28]. As organic food producers are not rewarded for continuous improvement, but have to comply just with minimum standards, they are incentivized to simply substitute prohibited with allowed inputs sourced from outside of the system. As a result they will be again locked into the vicious circles creating dependence on external inputs (R2, Figure 4; R4, Figure 5) with all their consequences for resilience of the prevailing food system.

In addition to better environmental outcomes, many studies have found that organic food producers perform better also in socio-economic terms as compared to their conventional counterparts $[21,30]$. Simply looking at comparisons of organic versus conventional short-term profitability, organic seems to be a promising option to preserve viability of farms. Besides, the organic food system is characterized also by diversity of markets (e.g., specialized organic food stores, farmers' markets and direct farm marketing, food baskets), through which organic food is provided to consumers [20]. These two features-better financial performance and diversity of markets-suggest that potentially the internal market structure of the organic food system is different from the conventional one and that the system can address the vulnerabilities related to socio-economic organization of food production inherent in the latter.

However, there are many signs indicating that organic food system based on certification of food production methods alone, falls into the same reinforcing mechanisms as conventional system and gives up its resilient features for efficiency (R5, Figure 7) and itself is vulnerable.

First, establishing certification put barriers for smaller food producers to enter the sector, because of incurred costs of certification and because it facilitates larger retailers to sell organic products [9]. 
Hence, the organic food system becomes more and more consolidated and losses its diversity, which has the same consequences for resilience as presented for the conventional European food system.

Second, higher profits realized by organic producers in comparison with conventional farmers are attributed mainly to price premiums paid by consumers and subsidies received from governments $[18,20,21]$. Some authors point out that the organic producers are becoming more and more dependent on the direct payments [149]. Such dependence makes organic producers increasingly vulnerable to changes in political environment. It is also uncertain, how much of the price premium is received because of willingness to pay or because of the anecdotal unprecedented growth in demand that outpace the growth in supply on the organic market [18], and hence what would happen with profits when the farm-gate prices for organic products fall [20,161].

Third, organic food producers compete with each other based solely on price, which does not internalize all externalities. It means that many of the socially and ecologically progressive attributes of organic produce are neglected in the price of organic food. Such a price-based competition disincentives the organic food producers from continuous improvement of their practices and involves them into the productivity paradigm and the reinforcing spiral of efficiency maximization (R5, Figure 7), violating many of the organic principles and reducing its potential to be a viable option for making the European food system more resilient $[20,28]$. This is evident in the organic 'conventionalization' and 'supermarketization' debate [20,28].

\section{Conclusions}

In this paper, we have proposed a new way to help policymakers understand the European food system's vulnerabilities and assess whether alternative developments such as organic farming can enhance its resilience. For this, we adopted a system dynamics approach to capture the dynamic complexity of the food system. We identified a number of key systemic vulnerabilities, including the degradation of the natural resource base of food production, the erosion of its tacit knowledge base, its dependence on external inputs and governmental support, the latent instability of the agri-food markets and the strive for efficiency that leads to a loss of diversity in the food system.

We have argued that organic farming has the potential to address these vulnerabilities, but at the same time risks falling into the same systemic pitfalls through a process of conventionalization. More specifically, organic farming as a food system has to be carefully designed and implemented to overcome the contradictions between the dominant socio-economic organization of food production and the ability to implement holistic understanding of organic principles on a broader scale. To make organic farming a viable strategy for reducing the vulnerabilities and enhancing the resilience of the European food system, certification as one of the main intervention proposed by the EU, for instance, will not be sufficient. Certification draws better boundaries around environmental resources and thus limits the negative environmental impacts that agricultural production has. However, it does not interfere with the production growth drivers and thus does not change the nature of any of the feedback mechanisms described in this paper nor does it affect their relative strength, i.e., the extent to which they dominate system's behavior.

Reducing vulnerabilities and increasing resilience of food systems goes beyond intervention engineering. The structural thinking tools developed in this paper provide a basis for an integrated evaluation of interventions, that is, of how interventions acknowledge that accumulation and draining processes cause delays and constraints in food systems' responses to disturbances, that feedback processes cause a reinforcement or dampening of such a response, and that nonlinearity causes an interaction between the response produced by various model components and across model components. The system-oriented approach helps also to characterize the range of synergies and trade-offs between food systems' outcomes that arise from such interventions.

Building on our structural diagram, further research could focus on other outcomes valued by different perspectives. Besides, the structural diagram serves also as a transition between mental models existing in literature and fully operational simulation models with which one could test the 
system's response to various types and magnitudes of disturbances and interventions. The system dynamics approach captures well the cross-level interactions (e.g., production and consumption) within food systems as long as the individual level is expressed in aggregated terms. Yet cross-scale (i.e., spatially disaggregated) interactions between the biophysical and decision-making, would require a hybrid approach, merging system dynamics with, for example, agent-based modelling [41].

Above and beyond, the understanding of systemic interactions and dynamic complexity of a food system is, however, not enough to identify specific actions and potential policies for increasing the resilience of any particular food system [162,163]. The concrete design and implementation of interventions requires also careful consideration of political agency (e.g., alternative food movements and actors) [14] and negotiation of power relations [164]. This opens up avenues for future research that establish a dialogue between social-ecological systems analyses with, for instance, political ecology ([162]).

Acknowledgments: This paper originates from an EU FP7 funded project TRANSMANGO “Assessment of the impact of global drivers of change on Europe's food security"; Grant agreement No. 613532; Theme KBBE.2013.2.5-01. Birgit Kopainsky is supported by the Norwegian Research Council through the project "Simulation based tools for linking knowledge with action to improve and maintain food security in Africa" (contract number 217931/F10). We are very grateful to Andreas Gerber for his very helpful feedback on earlier versions of this paper. We would like to thank the reviewers and the editors of this special issue for very useful comments and feedback.

Author Contributions: Natalia Brzezina, Birgit Kopainsky and Erik Mathijs conceived and designed the research; Natalia Brzezina and Birgit Kopainsky performed the research; Natalia Brzezina, Birgit Kopainsky and Erik Mathijs analyzed the data; Natalia Brzezina, Birgit Kopainsky and Erik Mathijs wrote the paper.

Conflicts of Interest: The authors declare no conflict of interest.

\section{Abbreviations}

The following abbreviations are used in this manuscript:

$\begin{array}{ll}\text { AWU } & \text { annual work unit } \\ \text { CAP } & \text { Common Agriculture Policy EU: European Union } \\ \text { FNS } & \text { Food and Nutrition Security } \\ \text { FNVA } & \text { farm net value added } \\ \text { NGO } & \text { non-governmental organization } \\ \text { R\&D } & \text { Research and Development } \\ \text { SES } & \text { social-ecological systems }\end{array}$

\section{References}

1. Marten, G.G.; Atalan-Helicke, N. Introduction to the Symposium on American Food Resilience. J. Environ. Stud. Sci. 2015, 5, 308-320. [CrossRef]

2. Hazell, P.; Wood, S. Drivers of change in global agriculture. Philos. Trans. R. Soc. B Biol. Sci. 2008, 363, 495-515. [CrossRef] [PubMed]

3. Swinnen, J.F.M.; Banerjee, A.N.; De Gorter, H. Economic development, institutional change, and the political economy of agricultural protection: An econometric study of Belgium since the 19th century. Agric. Econ. 2001, 26, 25-43. [CrossRef]

4. Kirchmann, H.; Thorvaldsson, G. Challenging targets for future agriculture. Eur. J. Agron. 2000, 12, 145-161. [CrossRef]

5. Hendrickson, M.K. Resilience in a concentrated and consolidated food system. J. Environ. Stud. Sci. 2015, 5, 418-431. [CrossRef]

6. Tansey, G. Food and thriving people: Paradigm shifts for fair and sustainable food systems. Food Energy Secur. 2013, 2, 1-11. [CrossRef]

7. International Assessment of Agricultural Knowledge, Science and Technology for Development. Agriculture at a Crossroads-Global Report. 2009. Available online: http://www.unep.org/dewa/agassessment/ reports/IAASTD/EN/Agriculture\%20at\%20a\%20Crossroads_Global\%20Report\%20(English).pdf (accessed on 1 February 2016). 
8. The 3rd SCAR Foresight Exercise. Sustainable Food Consumption and Production in a Resource-Constrained World. 2009. Available online: https://ec.europa.eu/research/agriculture/scar/pdf/scar_feg3_final_ report_01_02_2011.pdf (accessed on 1 February 2016).

9. Rotz, S.; Fraser, E.D.G. Resilience and the industrial food system: Analyzing the impacts of agricultural industrialization on food system vulnerability. J. Environ. Stud. Sci. 2015, 5, 459-473. [CrossRef]

10. Godfray, H.C.J.; Crute, I.R.; Haddad, L.; Lawrence, D.; Muir, J.F.; Nisbett, N.; Pretty, J.; Robinson, S.; Toulmin, C.; Whiteley, R. The future of the global food system. Philos. Trans. R. Soc. Lond. B Biol. Sci. 2010, 365, 2769-2777. [CrossRef] [PubMed]

11. Sundkvist, Å.; Milestad, R.; Jansson, A. On the importance of tightening feedback loops for sustainable development of food systems. Food Policy 2005, 30, 224-239. [CrossRef]

12. Ingram, J. A food systems approach to researching food security and its interactions with global environmental change. Food Secur. 2011, 3, 417-431. [CrossRef]

13. EUROSTAT 2014. Population and Population Change Statistics. Available online: http://ec.europa.eu/ eurostat/statistics-explained/index.php/Population_and_population_change_statistics (accessed on 20 August 2016).

14. Akram-Lodhi, A.H. Hungry for Change: Farmers, Food Justice and the Agrarian Question; Fernwood Publishing: Halifax, NS, Canada, 2013.

15. Stave, K.; Kopainsky, B. A system dynamics approach for examining mechanisms and pathways of food supply vulnerability. J. Environ. Stud. Sci. 2015, 5, 321-336. [CrossRef]

16. King, C.A. Community resilience and contemporary agri-ecological systems: Reconnecting people and food, and people with people. Syst. Res. Behav. Sci. 2008, 25, 111-124. [CrossRef]

17. Stolze, M.; Lampkin, N. Policy for organic farming: Rationale and concepts. Food Policy 2009, 34, $237-244$. [CrossRef]

18. International Federation of Organic Agriculture Movements. Organic in Europe: Prospects and Developments. 2016. Available online: http://www.ifoam-eu.org/sites/default/files/ifoameu_organic_ in_europe_2016.pdf (accessed on 10 March 2016).

19. Niggli, U. Sustainability of organic food production: Challenges and innovations. Proc. Nutr. Soc. 2015, 74, 83-88. [CrossRef] [PubMed]

20. Darnhofer, I. Contributing to a transition to sustainability of agri-food systems: Potentials and pitfalls for organic farming. In Organic Farming, Prototype for Sustainable Agricultures; Bellon, S., Penvern, S., Eds.; Springer: Dordrecht, The Netherlands; Heidelberg, Germany; New York, NY, USA; London, UK, 2014; pp. 439-452.

21. Reganold, J.P.; Wachter, J.M. Organic agriculture in the twenty-first century. Nat. Plants 2016, 2, 15221. [CrossRef] [PubMed]

22. Food Security Information Network. Resilience Measurement Principles. 2014. Available online: http:/ / www.fao.org/fileadmin/user_upload/drought/docs/FSIN\%20Resilience\%20Measurement\% 20201401.pdf (accessed on 20 March 2016).

23. Milestad, R.; Darnhofer, I. Building farm resilience: The prospects and challenges of organic farming. J. Sustain. Agric. 2003, 22, 81-97. [CrossRef]

24. Food and Agriculture Organization. Building Resilience for an Unpredictable Future: How Organic Agriculture Can Help Farmers Adapt to Climate Change. 2006. Available online: http:/ /www.fao.org/3/aah617e.pdf (accessed on 30 March 2016).

25. Darnhofer, I. Strategies of family farms to strengthen their resilience. Environ. Policy Gov. 2010, 20, $212-222$. [CrossRef]

26. Scialabba, N.E.-H.; Müller-Lindenlauf, M. Organic agriculture and climate change. Renew. Agric. Food Syst. 2010, 25, 158-169. [CrossRef]

27. Little Unix Programmers Group. The Role of Agroecology in Sustainable Intensification. 2015. Available online: http:/ / www.snh.gov.uk/docs/A1652615.pdf (accessed on 1 February 2016).

28. Guthman, J. Agrarian Dreams: The Paradox of Organic Farming in California; University of California Press: Berkeley, CA, USA; Los Angeles, CA, USA; London, UK, 2004.

29. De Ponti, T.; Rijk, B.; Van Ittersum, M.K. The crop yield gap between organic and conventional agriculture. Agric. Syst. 2012, 108, 1-9. [CrossRef] 
30. Crowder, D.W.; Reganold, J.P. Financial competitiveness of organic agriculture on a global scale. Proc. Natl. Acad. Sci. USA 2015, 112, 7611-7616. [CrossRef] [PubMed]

31. Gomiero, T.; Pimentel, D.; Paoletti, M.G. Environmental impact of different agricultural management practices: Conventional vs. organic agriculture. CRC Crit. Rev. Plant Sci. 2011, 30, 95-124. [CrossRef]

32. Palupi, E.; Jayanegara, A.; Ploeger, A.; Kahl, J. Comparison of nutritional quality between conventional and organic dairy products: A meta-analysis. J. Sci. Food Agric. 2012, 92, 2774-2781. [CrossRef] [PubMed]

33. European Commission. Farm Economics Briefs 2013. Organic versus Conventional Farming, Which Performs Better Financially? Available online: http:/ / ec.europa.eu/agriculture/rica/pdf/FEB4_Organic_farming_ final_web.pdf (accessed on 10 March 2016).

34. Birkhofer, K.; Bezemer, T.M.; Bloem, J.; Bonkowski, M.; Christensen, S.; Dubois, D.; Ekelund, F.; Fließbach, A.; Gunst, L.; Hedlund, K.; et al. Long-term organic farming fosters below and aboveground biota: Implications for soil quality, biological control and productivity. Soil Biol. Biochem. 2008, 40, 2297-2308. [CrossRef]

35. Bengtsson, J.; Ahnström, J.; Weibull, A.-C. The effects of organic agriculture on biodiversity and abundance: A meta-analysis. J. Appl. Ecol. 2005, 42, 261-269. [CrossRef]

36. Tuomisto, H.L.; Hodge, I.D.; Riordan, P.; Macdonald, D.W. Does organic farming reduce environmental impacts?-A meta-analysis of European research. J. Environ. Manag. 2012, 112, 309-320. [CrossRef] [PubMed]

37. Ericksen, P.J. Conceptualizing food systems for global environmental change research. Glob. Environ. Chang. 2008, 18, 234-245. [CrossRef]

38. Cash, D.W.; Adger, W.; Berkes, F.; Garden, P.; Lebel, L.; Olsson, P.; Pritchard, L.; Young, O. Scale and cross-scale dynamics: Governance and information in a multilevel world. Ecol. Soc. 2006, 11, 8.

39. Ericksen, P.J. What is the vulnerability of a food system to global environmental change? Ecol. Soc. 2008, 13,14 .

40. Hammond, R.; Dubé, L. A systems science perspective and transdisciplinary models for food and nutrition security. Proc. Natl. Acad. Sci. USA 2012, 109, 12356-12363. [CrossRef] [PubMed]

41. Kopainsky, B.; Huber, R.; Pedercini, M. Food provision and environmental goals in the Swiss agri-food system: System dynamics and the social-ecological systems framework. Syst. Res. Behav. Sci. 2015, 432, 414-432. [CrossRef]

42. Schlüter, M.; Mcallister, R.R.J.; Arlinghaus, R.; Bunnefeld, N.; Eisenack, K.; Hölker, F.; Milner-Gulland, E.J.; Müller, B.; Nicholson, E.; Quaas, M.; et al. New horizons for managing the enviornment: A review of coupled social-ecological systems modeling. Nat. Resour. Model. 2012, 25, 219-272. [CrossRef]

43. Schlüter, M.; Hinkel, J.; Bots, P.W.G.; Arlinghaus, R. Application of the SES framework for model-based analysis of the dynamics of social-ecological systems. Ecol. Soc. 2014, 19, 36. [CrossRef]

44. Alroe, H.F.; Noe, E. Second-order science of interdisciplinary research a polyocular framework for wicked problems. Constr. Found. 2014, 10, 65-76.

45. Sterman, J. Business Dynamics: Systems Thinking and Modeling for a Complex World; McGraw-Hill Higher Education: Toronto, ON, Canada, 2000.

46. Tendall, D.M.; Joerin, J.; Kopainsky, B.; Edwards, P.; Shreck, A.; Le, Q.B.; Kruetli, P.; Grant, M.; Six, J. Food system resilience: Defining the concept. Glob. Food Secur. 2015, 6, 17-23. [CrossRef]

47. Ingram, J.; Ericksen, P.; Liverman, D. Food Security and Global Environmental Change; Earthscan: London, UK; Washington, DC, USA, 2010.

48. Quinlan, A.E.; Berbés-Blázquez, M.; Haider, L.J.; Peterson, G.D. Measuring and assessing resilience: Broadening understanding through multiple disciplinary perspectives. J. Appl. Ecol. 2015, 53, 677-687. [CrossRef]

49. Ford, A. Modeling the Environment, 2nd ed.; Island Press: Washington, DC, USA, 2009.

50. System Dynamics Society. Intrdocution to System Dynamics. Available online: http://www. systemdynamics.org/what-is-s/ (accessed on 10 March 2016).

51. Forrester, J. Industrial Dynamics; MIT Press: Cambridge, MA, USA, 1961.

52. Lane, D.C. Should system dynamics be desribed as a "hard" or a "deterministic" systems approach? Syst. Res. Behav. Sci. 2000, 17, 3-22. [CrossRef]

53. Ford, J.D. Vulnerability of Inuit food systems to food insecurity as a consequence of climate change: A case study from Igloolik, Nunavut. Reg. Environ. Chang. 2009, 9, 83-100. [CrossRef]

54. Hoffman, M.H.G. Cognitive conditions of diagrammatic reasoning. Semiotics 2011, 186, 189-212. [CrossRef] 
55. Barlas, Y.; Carpenter, S. Philosophical roots of model validation: Two paradigms. Syst. Dyn. Rev. 1990, 6, 148-166. [CrossRef]

56. Lane, D.C. With a little help from our friends: How system dynamics and soft OR can learn from each other. Syst. Dyn. Rev. 1994, 10, 101-134. [CrossRef]

57. Vennix, J.A.M. Group Model Building: Facilitating Team Learning Using System Dynamics; Wilety: Chichester, UK, 1996.

58. Lane, D.C. Social theory and system dynamics practice. Eur. J. Oper. Res. 1999, 113, 501-527. [CrossRef]

59. Richardson, G.P. Feedback thought in Social Science and Systems Theory; University of Pennsylvania Press: Philadelphia, PA, USA, 1991.

60. Burell, G.; Morgan, G. Sosiological Paradigms and Organisational Analysis: Elements of the Sociology of Corporate Life; Gower: Aldershot, UK, 1979.

61. Lane, D.C.; Oliva, R. The greater whole: Towards a synthesis of system dynamics and soft systems methodology. Eur. J. Oper. Res. 1998, 107, 214-235. [CrossRef]

62. Lane, D.C. Rerum cognoscere causas: Part I-How do the ideas of system dynamics relate to traditional social theories and the voluntarism/determinism debate? Syst. Dyn. Rev. 2001, 17, 97-118. [CrossRef]

63. Lane, D.C. Rerum cognoscere causas: Part II-Opportunities generated by the agency/structure debate and suggestions for clarifying the social theoretic position of system dynamics. Syst. Dyn. Rev. 2001, 17, $293-309$. [CrossRef]

64. A Sustainability Institute Report 2003. Commodity System Challenges Moving Sustainability into the Mainstream of Natural Resource Economies. Available online: http:/ /s3.amazonaws.com/zanran_storage/ www.ediblestrategies.com/ContentPages/707629742.pdf (accessed on 12 December 2015).

65. European Commission. The Common Agriculture Policy-A Story to Be Continued. Available online: http:/ / ec.europa.eu/agriculture/50-years-of-cap/files/history/history_book_lr_en.pdf (accessed on 20 April 2016).

66. European Commission. 50 Years of Food Safety in the EU. 2007. Available online: http://ec.europa.eu/ food/food/docs/50years_foodsafety_en.pdf (accessed on 20 April 2016).

67. Food and Agriculture Organization. World Outlook and State of Food and Agriculture-1950. Available online: http://www.fao.org/docrep/016/ap638e/ap638e.pdf (accessed on 1 February 1950).

68. Economist Intelligence Unit (EIU). Food Security in Focus: Europe. $2014 . \quad$ Available online: http:/ / foodsecurityindex.eiu.com/Home/DownloadResource?fileName=EIU\%20GFSI\%202014_ Europe\%20regional\%20report.pdf (accessed on 20 March 2016).

69. EU Agricultural Outlook. Prospects for EU Agricultural Markets and Income 2015-2025. Available online: http:/ / ec.europa.eu/agriculture/markets-and-prices/medium-term-outlook/2015/fullrep_en.pdf (accessed on 1 February 2016).

70. De Vries, B.J.M. Sustainability Science; Cambridge University Press: New York, NY, USA, 2013.

71. Brisson, N.; Gate, P.; Gouache, D.; Charmet, G.; Oury, F.X.; Huard, F. Why are wheat yields stagnating in Europe? A comprehensive data analysis for France. Field Crop. Res. 2010, 119, 201-212. [CrossRef]

72. Grassini, P.; Eskridge, K.M.; Cassman, K.G. Distinguishing between yield advances and yield plateaus in historical crop production trends. Nat. Commun. 2013, 4, 2918. [CrossRef] [PubMed]

73. European Commission. EU Agricultural Markets Briefs. Price Developments and Links to Food Security-Price Level and Volatility. 2015. Available online: http:/ /ec.europa.eu/agriculture/markets-andprices/market-briefs/pdf/05_en.pdf (accessed on 10 March 2016).

74. European Commission. Communication from the Commission to the European Parliament, the Council, the European Economic and Social Committee and the Committee of the Regions-Food Prices in Europe. 2008. Available online: http://eur-lex.europa.eu/legal-content/EN/TXT/PDF/?uri=CELEX: 52008DC0821\&from=EN (accessed on 1 February 2016).

75. Loopstra, R.; Reeves, A.; Stuckler, D. Rising food insecurity in Europe. Lancet 2015, 385, 2041. [CrossRef]

76. World Health Organization. Obesity Europe. Available online: http://www.euro.who.int/en/health-topics/ noncommunicable-diseases/obesity (accessed on 20 March 2016).

77. European Commission. EC Farm Economics Briefs 2011. Income Developments in EU Farms. Available online: http:/ / ec.europa.eu/agriculture/rica/pdf/Brief201101.pdf (accessed on 10 March 2016).

78. European Commission. EC Farm Economics Briefs 2011. EU Production Costs Overview. Available online: http:/ / ec.europa.eu/agriculture/rica/pdf/Brief201102.pdf (accessed on 10 March 2016). 
79. European Commission. EU Agricultural Economics Briefs 2013. Structure and Dynamics of EU Farms: Changes, Trends and Policy Relevance. Available online: http://ec.europa.eu/agriculture/rural-areaeconomics/briefs/pdf/09_en.pdf (accessed on 10 March 2016).

80. European Commission. EU Agricultural Economics Briefs 2014. EU Agricultural Income 2014-First Estimates. Available online: http://ec.europa.eu/agriculture/rural-area-economics/briefs/pdf/003_en.pdf (accessed on 10 March 2016).

81. European Commission. EU Agricultural and Farm Economics Briefs 2015. EU Farm Economics Summary 2012. Available online: http://ec.europa.eu/agriculture/rural-area-economics/briefs/pdf/003_en.pdf (accessed on 10 March 2016).

82. Vrolijk, H.C.J.; De Bont, C.J.A.M.; Blokland, P.W.; Soboh, R.A.M.E. Farm Viability in the European Union Assessment of the Impact of Changes in Farm Payments 2010. Available online: http:/ / edepot.wur.nl/138917 (accessed on 10 March 2016).

83. Matthews, A. FADN Data Highlights Dependence of EU Farms on Subsidy Payments. Available online: http:/ / capreform.eu/fadn-data-highlights-dependence-of-eu-farms-on-subsidy-payments / (accessed on 10 March 2016).

84. Enjolras, G.; Capitanio, F.; Aubert, M.; Adinolfi, F. Direct payments, crop insurance and the volatility of farm income. Some evidence in France and in Italy. New Medit 2014, 13, 31-40.

85. Rabobank. Rethinking the F\&A Supply Chain. Impact of Agricultural Price Volatility on Sourcing Strategies. 2011. Available online: http://www.boerderij.nl/pagefiles/35979/002_boerderij-download-agd573390d01. pdf (accessed on 10 March 2016).

86. Matthews, A. Recent Trends in EU Farm Incomes 2016. Available online: http://capreform.eu/recenttrends-in-eu-farm-incomes/ (accessed on 10 March 2016).

87. European Environment Agency. Agriculture. Available online: http://www.eea.europa.eu/themes/ agriculture/intro (accessed on 20 March 2016).

88. Stoate, C.; Báldi, A.; Beja, P.; Boatman, N.D.; Herzon, I.; van Doorn, A.; De Snoo, G.R.; Rakosy, L.; Ramwell, C. Ecological impacts of early 21st century agricultural change in Europe-A review. J. Environ. Manag. 2009, 91, 22-46. [CrossRef] [PubMed]

89. Rockstrom, J.; Steffen, W.; Noone, K.; Persson, Å.; Chapin, F.S.; Lambin, E.; Lenton, T.M.; Scheffer, M.; Folke, C.; Schellnhuber, H.; et al. Planetary boundaries: Exploring the safe operating space for humanity. Ecol. Soc. 2009, 14, 32. [CrossRef]

90. European Commission. Proposal for a Regulation of the European Parliament and the Council Establishing Rules for Direct Payments to Farmers under Support Schemes within the Framework of the Common Agricultural Policy. 2011. Available online: http://ec.europa.eu/agriculture/cap-post-2013/legalproposals/com625/625_en.pdf (accessed on 20 March 2016).

91. Pe'er, G.; Dicks, L.V.; Visconti, P.; Arlettaz, R.; Báldi, A.; Benton, T.G.; Collins, S.; Dieterich, M.; Gregory, R.D.; Hartig, F.; et al. TEEB Agriculture policy. EU agricultural reform fails on biodiversity. Science 2014, 344, 1090-1092. [CrossRef] [PubMed]

92. Batáry, P.; Dicks, L.V.; Kleijn, D.; Sutherland, W.J. The role of agri-environment schemes in conservation and environmental management. Conserv. Biol. 2015, 29, 1006-1016. [CrossRef] [PubMed]

93. Erjavec, K.; Erjavec, E. "Greening the CAP"-Just a fashionable justification? A discourse analysis of the 2014-2020 CAP reform documents. Food Policy 2015, 51, 53-62. [CrossRef]

94. Swinnen, J. The Political Economy of the 2014-2020 Common Agricultural Policy-An Imperfect Strom; Centre for European Policy Studies (CEPS): Brussels, Belgium, 2015.

95. European Environmental Agency. Food Security and Environmental Impacts. 2012. Available online: http:/ / www.eea.europa.eu/themes/agriculture/greening-agricultural-policy/food-security-andenvironmental-impacts (accessed on 20 March 2016).

96. Levers, C.; Butsic, V.; Verburg, P. H.; Müller, D. Drivers of changes in agricultural intensity in Europe. Land Use Policy 2016, 58, 380-393. [CrossRef]

97. La Trobe, H.L.; Acott, T.G.; La Trobd, H.L.; Acotp, T.G. Localising the global food system. Int. J. Sustain. Dev. World Ecol. 2000, 7, 309-320. [CrossRef]

98. Cordell, D.; Neset, T.-S.S. Phosphorus vulnerability: A qualitative framework for assessing the vulnerability of national and regional food systems to the multi-dimensional stressors of phosphorus scarcity. Glob. Environ. Chang. 2014, 24, 108-122. [CrossRef] 
99. Neset, T.-S.S.; Cordell, D. Global phosphorus scarcity: Identifying synergies for a sustainable future. J. Sci. Food Agric. 2012, 92, 2-6. [CrossRef] [PubMed]

100. Cordell, D.; Drangert, J.-O.; White, S. The story of phosphorus: Global food security and food for thought. Glob. Environ. Chang. 2009, 19, 292-305. [CrossRef]

101. Wallgren, C.; Mattias, H. Eating energy-Identifying possibilities for reduced energy use in the future food supply system. Energy Policy 2009, 37, 5803-5813. [CrossRef]

102. Pfeiffer, D.A. Eating Fossil Fuels; The Wilderness Publications: London, UK, 2003.

103. Olesen, J.E.; Schelde, K.; Weiske, A.; Weisbjerg, M.R.; Asman, W.A.H.; Djurhuus, J. Modelling greenhouse gas emissions from European conventional and organic dairy farms. Agric. Ecosyst. Environ. 2006, 112, 207-220. [CrossRef]

104. The 1st SCAR Foresight Exercise. Agriculture and Environment 2006. Available online: https://ec.europa. eu/research/agriculture/scar/pdf/scar_foresight_environment_en.pdf (accessed on 1 February 2016).

105. ESF/COST Forward Look on European Food Systems in a Changing World. 2009. Available online: http://www.esf.org/fileadmin/Public_documents/Publications/food.pdf (accessed on 1 February 2016).

106. The Government Office for Science. Foresight. The Future of Food and Farming. 2011. Final Project Report. Available online: https://www.gov.uk/government/uploads/system/uploads/attachment_data/ file/288329/11-546-future-of-food-and-farming-report.pdf (accessed on 1 February 2016).

107. Tilman, D.; Cassman, K.G.; Matson, P.A.; Naylor, R.; Polasky, S. Agriculture sustainability and intensive production practices. Nature 2002, 418, 671-677. [CrossRef] [PubMed]

108. Ramírez, C.A.; Worrell, E. Feeding fossil fuels to the soil. An analysis of energy embedded and technological learning in the fertilizer industry. Resour. Conserv. Recycl. 2006, 46, 75-93. [CrossRef]

109. Shcherbak, I.; Millar, N.; Robertson, G.P. Global metaanalysis of the nonlinear response of soil nitrous oxide (N2O) emissions to fertilizer nitrogen. Proc. Natl. Acad. Sci. USA 2014, 111, 9199-9204. [CrossRef] [PubMed]

110. Geiger, F.; Bengtsson, J.; Berendse, F.; Weisser, W.W.; Emmerson, M.; Morales, M.B.; Ceryngier, P.; Liira, J.; Tscharntke, T.; Winqvist, C.; et al. Persistent negative effects of pesticides on biodiversity and biological control potential on European farmland. Basic Appl. Ecol. 2010, 11, 97-105. [CrossRef]

111. Mclaughlin, A.; Mineau, P. The impact of agricultural practices on biodiversity. Agric. Ecosyst. Environ. 1995, 55, 201-212. [CrossRef]

112. Food and Agriculture Organization. Livestock's Long Shadow Environmental Issues and Options. Available online: ftp:/ /ftp.fao.org/docrep/fao/010/a0701e/a0701e.pdf (accessed on 20 March 2016).

113. Tamminga, S. Pollution due to nutrient losses and its control in European animal production. Livest. Prod. Sci. 2003, 84, 101-111. [CrossRef]

114. Goodman, D.; Sorj, B.; Wilkinson, J. From Farming to Biotechnology: A Theory of Agro-Industrial Development; Basil Blackwell: Oxford, UK, 1987.

115. Lundvall, B.; Johnson, B. The learning economy. J. Ind. Stud. 1994, 1, 23-42. [CrossRef]

116. United Nations Industrial Development Organization. Determinants of Total Factor Productivity: A Literature Review. 2007. Available online: http://www.unido.org//fileadmin/user_media/Publications / Research_and_statistics/Branch_publications/Research_and_Policy/Files/Working_Papers/2007/ WP022007\%20-\%20Determinants\%20of\%20total\%20factor\%20productivity.pdf (accessed on 20 March 2016).

117. Morgan, K.; Murdoch, J. Organic vs. conventional agriculture: Knowledge, power and innovation in the food chain. Geoforum 2000, 31, 159-173. [CrossRef]

118. Mitchell, D. A Note on Rising Food Prices; Policy Research Working Paper 4682; World Bank: Washington, DC, USA, 2008. Available online: http://elibrary.worldbank.org/doi/abs/10.1596/1813-9450-4682 (accessed on 20 March 2016).

119. Ciaian, P.; Kancs, A. Interdependencies in the energy-bioenergy-food price systems: A cointegration analysis. Resour. Energy Econ. 2011, 33, 326-348. [CrossRef]

120. Abbott, P.C.; Hurt, C.; Tyner, W.E. What's Driving Food Prices?; Farm Fundation Issue Report; Farm Fundation: Oak Brook, IL, USA, 2009. Available online: http://www.farmfoundation.org/news/articlefiles/105FoodPrices_web.pdf (accessed on 20 March 2016).

121. Lipsky, J. Commodity Prices and Global Inflation. In Proceedings of the Council on Foreign Relations, New York, NY, USA, 8 May 2008.

122. Organisation for Economic Co-operation and Development. OECD-FAO Agricultural Outlook 2009-2018. Available online: http:/ / www.oecd.org/berlin/43042301.pdf (accessed on 20 March 2016). 
123. Food and Agriculture Organization. Growing demand on agriculture and rising prices of commodities: An opportunity for smallholders in low-income, agricultural-based countries? In Proceedings of the Thirty-First Session of IFAD's Governing Council, Rome, Italy, 14 February 2008.

124. Headey, D.; Fan, S. Anatomy of a crisis: The causes and consequences of surging food prices. Agric. Econ. 2008, 39, 375-391. [CrossRef]

125. Pendell, D.L.; Kim, Y.; Herbel, K. Differences Between High-, Medium-, and Low-Profit Cow-Calf Producers: An Analysis of 2010-2014 Kansas Farm Management Association Cow-Calf Enterprise. 2015. Available online: https://www.agmanager.info/sites/default/files/Cow-Calf_2015_1.pdf (accessed on 20 March 2016).

126. United States Department of Agriculture. Profits, Costs, and the Changing Structure of Dairy Farming; Economic Research Report 47; USDA: Washington, DC, USA, 2007.

127. Sgroi, F.; Maria, A.; Trapani, D.; Testa, R.; Tudisca, S. Strategy to increase the farm competitiveness. Am. J. Agric. Biol. Sci. 2014, 9, 394-400. [CrossRef]

128. Karelakis, C.; Abas, Z.; Galanopoulos, K.; Polymeros, K. Positive effects of the Greek economic crisis on livestock farmer behaviour. Agron. Sustain. Dev. 2013, 33, 445-456. [CrossRef]

129. Rasmussen, S. Production Economics: The Basic Theory of Production Optimisation, 2nd ed.; Springer: Heidelberg, Germany; New York, NY, USA; Dordrecht, The Nertherlands; London, UK, 2011.

130. Debertin, D.L. Agricultura Production Economics, 2nd ed.; Macmillan Publishing Company: New York, NY, USA, 2012.

131. Varian, H.R. Intermediate Microeconomics, 8th ed.; WW Norton \& Co.: New York, NY, USA; London, UK, 2010.

132. Bragg, L.A.; Dalton, T.J. Factors affecting the decision to exit dairy farming: A two-stage regression analysis. J. Dairy Sci. 2004, 87, 3092-3098. [CrossRef]

133. Foltz, J.D. Entry, exit, and farm size: Assessing an experiment in dairy price policy. Am. J. Agric. Econ. 2004, 86, 594-604. [CrossRef]

134. Ferguson, R.; Hansson, H. Expand or exit? Strategic decisions in milk production. Livest. Sci. 2013, 155, 415-423. [CrossRef]

135. Breustedt, G.; Glauben, T. Driving forces behind exiting from farming in Western Europe. J. Agric. Econ. 2007, 58, 115-127. [CrossRef]

136. Cochrane, W.W. Farm Price: Myth and Reality; University of Minnesota Press: St. Paul, MN, USA, 1958.

137. Adger, W.N. Vulnerability. Glob. Environ. Chang. 2006, 16, 268-281. [CrossRef]

138. O’Brien, K.; Leichenko, R.; Kelkar, U.; Venema, H.; Aandahl, G.; Tompkins, H.; Javed, A.; Bhadwal, S.; Barg, S.; Nygaard, L.; et al. Mapping vulnerability to multiple stressors: Climate change and globalization in India. Glob. Environ. Chang. 2004, 14, 303-313. [CrossRef]

139. Magdoff, F. Food as a commodity. Mon. Rev. 2012, 63, 15-22. [CrossRef]

140. Westhoek, H.J.; Overmars, K.P.; van Zeijts, H. The provision of public goods by agriculture: Critical questions for effective and efficient policy making. Environ. Sci. Policy 2013, 32, 5-13. [CrossRef]

141. Harvey, D.; Hubbard, C. Reconsidering the political economy of farm animal welfare: An anatomy of market failure. Food Policy 2013, 38, 105-114. [CrossRef]

142. Ciaian, P.; Swinnen, J.F.M. Market imperfections and agricultural policy effects on structural change and competitiveness in an Enlarged EU. In Proceedings of the XIth Congress of the European Association of Agricultural Economists, 'The Future of Europe in the Global Agri-Food System', Copenhagen, Denmark, 24-27 August 2005.

143. Ciaian, P.; Swinnen, J.F.M. Credit market imperfections and the distribution of policy rents. Am. J. Agric. Econ. 2009, 91, 1124-1139. [CrossRef]

144. Ciaian, P.; Swinnen, J.F.M. Land market imperfections and agricultural policy impacts in the new EU Member States: A partial equilibrium analysis. Am. J. Agric. Econ. 2006, 88, 799-815. [CrossRef]

145. Cohen, B.; Winn, M.I. Market imperfections, opportunity and sustainable entrepreneurship. J. Bus. Ventur. 2007, 22, 29-49. [CrossRef]

146. McCorriston, S. Why should imperfect competition matter to agricultural economists? Eur. Rev. Agric. Econ. 2002, 29, 349-371. [CrossRef]

147. Soregaroli, C.; Sckokai, P.; Moro, D. Agricultural policy modelling under imperfect competition. J. Policy Model. 2011, 33, 195-212. [CrossRef] 
148. Matsumoto, A. Do government subsidies stabilize or destabilize agricultural markets? Contemp. Econ. Policy 1998, 452-466. [CrossRef]

149. Offermann, F.; Nieberg, H.; Zander, K. Dependency of organic farms on direct payments in selected EU member states: Today and tomorrow. Food Policy 2009, 34, 273-279. [CrossRef]

150. Garrido, A.; Brummer, B.; M’Barek, R.; Meuwissen, M.P.M.; Morales-Opazo, C. Agriculture Markets Instability: Revisiting the Recent Food Crises; Routledge: London, UK, 2016.

151. Chavas, J.-P.; Holt, M.T. Market instability and nonlinear dynamics. Am. J. Agric. Econ. 1993, 75, 113. [CrossRef]

152. Meadows, D.L. The Dynamics of Commodity Production Cycles: A Dynamic Cobweb Theorem; Wright-Allen Press, Inc.: Cambridge, MA, USA, 1970.

153. Alexandratos, N. Food price surges: Possible causes, past experience, and longer term relevance. Popul. Dev. Rev. 2008, 34, 663-697. [CrossRef]

154. EUROSTAT 2016. Agri-Environmental Indicator-Specialisation. Available online: http://ec.europa.eu/ eurostat/statistics-explained/index.php/Agri-environmental_indicator_-_specialisation (accessed on 20 August 2016).

155. Smit, B.; Wandel, J. Adaptation, adaptive capacity and vulnerability. Glob. Environ. Chang. 2006, 16, $282-292$. [CrossRef]

156. Mondelaers, K.; Aertsens, J.; Huylenbroeck, G. Van A meta-analysis of the differences in environmental impacts between organic and conventional farming. Br. Food J. 2009, 111, 1098-1119. [CrossRef]

157. Sandhu, H.S.; Wratten, S.D.; Cullen, R. Organic agriculture and ecosystem services. Environ. Sci. Policy 2010, 13, 1-7. [CrossRef]

158. Gattinger, A.; Muller, A.; Haeni, M.; Skinner, C.; Fliessbach, A.; Buchmann, N.; Mäder, P.; Stolze, M.; Smith, P.; El-Hage Scialabbad, N.; et al. Enhanced top soil carbon stocks under organic farming. Proc. Natl. Acad. Sci. USA 2012, 109, 18226-18231. [CrossRef] [PubMed]

159. Seufert, V.; Ramankutty, N.; Foley, J.A. Comparing the yields of organic and conventional agriculture. Nature 2012, 485, 229-232. [CrossRef] [PubMed]

160. Lamine, C. Transition pathways towards a robust ecologization of agriculture and the need for system redesign. Cases from organic farming and IPM. J. Rural Stud. 2011, 27, 209-219. [CrossRef]

161. Smith, E.; Marsden, T. Exploring the "limits to growth" in UK organics: Beyond the statistical image. J. Rural Stud. 2004, 20, 345-357. [CrossRef]

162. Foran, T.; Butler, J.R.A.; Williams, L.J.; Wanjura, W.J.; Hall, A.; Carter, L.; Carberry, P.S. Taking complexity in food systems seriously: An interdisciplinary analysis. World Dev. 2014, 61, 85-101. [CrossRef]

163. Eakin, H.; Winkels, A.; Sendzimir, J. Nested vulnerability: Exploring cross-scale linkages and vulnerability teleconnections in Mexican and Vietnamese coffee systems. Environ. Sci. Policy 2009, 12, 398-412. [CrossRef]

164. Avelino, F.; Wittmayer, J.M. Shifting power relations in sustainability transitions: A multi-actor perspective. J. Environ. Policy Plan. 2015, 18, 628-649. [CrossRef]

(C) 2016 by the authors; licensee MDPI, Basel, Switzerland. This article is an open access article distributed under the terms and conditions of the Creative Commons Attribution (CC-BY) license (http://creativecommons.org/licenses/by/4.0/). 